\title{
Power, Environmental Principles and the International Court of Justice
}

\author{
Afshin Akhtarkhavari*
}

\section{Introduction}

This article discusses the role and function of environmental principles in terms of how they interplay with or constitute power in the context of the International Court of Justice (ICJ) developing and delivering its written judgments. The interaction of litigants with each other and the Bench of the ICJ is important not only for conveying facts and positions on the law; it shapes how the Court itself learns what its views are on legal issues. The idea that the process of litigation can generate common knowledge which is shared amongst the judges of the Bench and potentially states which might appear before the Court, as well as the future constituency of the ICJ, is the kind of collective social learning that forms the basis of the discussion in this article. It argues that the focus on social learning highlights the significant role that environment principles can play in decisions of the ICJ, notwithstanding their infrequent and direct use in the Court's determination of the legal position of the parties before it. The focus on social learning suggests that discussions on the rule of law ignore the power the ICJ has to shape disputes before it. It also misses the potential of certain kinds of norms to influence disputes and the resolution of them before powerful institutions like the ICJ.

Institutions like the ICJ do not just solve disputes based on what the parties to a case have argued are the right and wrong interpretations of the law and the facts of the case. ${ }^{1}$ Functionalist approaches to courts and dispute-resolution bodies can appear disparagingly uninterested in the political character of their work. ${ }^{2}$ This is partly symptomatic of the idea that institutions - especially dispute-resolution bodies - are meant to apply their authority without bias or dispositions that favour anything outside of their immediate jurisdiction. ${ }^{3}$ Courts are meant to apply rules

* $\quad$ Senior Lecturer $(\mathrm{PhD})$ at the Griffith Law School. I wish to thank Professor Rothwell who helped me greatly in shaping this and other recent scholarly activities of mine. I also wish to thank the independent reviewer who commented on this work.

1 For a general overview of the role of the ICJ in dispute resolution internationally, see J Merrills, International Dispute Settlement ( $4^{\text {th }}$ ed, 2006); J Collier and V Lowe, The Settlement of Disputes in International Law: Institutions and Procedures (1999) esp ch 7.

2 On a critique of the functionalist reaction to international organizations, see M Barnett and M Finnemore, 'The Power of Liberal International Organizations' in M Barnett and R Duvall (eds), Power in Global Governance (2005) 161.

3 Ibid 175. See also C Shore and S Wright, 'Policy: A New Field of Anthropology' in C Shore and S Wright (eds), Anthropology of Social Policy: Critical Perspectives on 
in a neutral and direct way, and anything else is viewed as an inappropriate exercise of their power. ${ }^{4}$ This is hardly the case, however, as shown by an abundance of research. ${ }^{5}$ When the ICJ adjudicates disputes and delivers the reasons for its decisions, it is also contributing more generally to change in international law and politics rather than simply applying in a neutral way a set of rules to the facts before it. ${ }^{6}$

It has been argued that judgments of the ICJ can contribute to change for reasons other than that they are 'legally binding'. ${ }^{7}$ It is their persuasiveness that determines the extent to which states will refer to or avoid them. ${ }^{8}$ Jennings points to the 'practical authority and power' associated with certain judgments that determine their relative impact on states and their use as a precedent for the ICJ. ${ }^{9}$ These ideas encapsulate the potential that international organisations like the ICJ have to exercise authority and power over 'knowledge claims', or the deference that states show to their claims to certain types and kinds of 'knowledge and truth'. ${ }^{10}$ In other words, they highlight the potential role or function of the ICJ to

Governance and Power (1997) 3.

For instance, commentators criticised the ICJ for its pragmatic rather than strict legal reaction to the Nuclear Tests Cases (New Zealand v France) (Interim Measures) [1973] ICJ Rep 135, (Merits) [1974] ICJ Rep 457: R St J McDonald and B Hough, 'The Nuclear Tests Case Revisited' (1977) 20 German Yearbook of International Law 337; T Franck, 'World Made Law: The Decision of the ICJ in the Nuclear Tests Cases' (1975) 69 American Journal of International Law 612; J J Ruiz, 'Mootness in International Adjudication: The Nuclear Tests Cases' (1977) 20 German Yearbook of International Law 358.

5 Generally, see, M Byers, Custom, Power and the Power of Rules: International Relations and Customary International Law (1999) esp 120-24; A Coleman, 'The International Court of Justice and Highly Political Matters' (2003) 4 Melbourne Journal of International Law 29; J Wessel, 'Judicial Policy-Making at the International Criminal Court: An Institutional Guide to Analyzing International Adjudication' (2006) 44 Columbia Journal of Transnational Law 377; T Ginsburg, 'Bounded Discretion in International Judicial Lawmaking' (2005) 45 Virginia Journal of International Law 631. For an insightful review of the way the ICJ exercised its 'judicial-legislative function' in the area of the law relating to international watercourses in the Case Concerning the Gabcikovo-Nagymaros Project (Hungary/Slovakia) [1997] ICJ Rep 7, see E Benvenisti, 'Customary International Law as a Judicial Tool for Promoting Efficiency' in E Benvenisti and M Hirsch (eds), The Impact of International Law on International Cooperation (2004) 85.

6 For similar ideas in the context of other courts and tribunals, see D Kennedy, $A$ Critique of Adjudication (fin de siecle) (1997); J Trachtman, 'The Domain of WTO Dispute Resolution' (1999) 40 Harvard International Law Journal 333. For a more direct study of the impact of the international dispute resolution bodies on international environmental governance, see T Stephens, International Courts and Environmental Protection (2008).

7 For example, Byers, Custom, Power and the Power of Rules, above n 5, 122.

8 Ibid.

9 R Jennings, 'The Judiciary, International and National, and the Development of International Law' (1996) 45 International and Comparative Law Quarterly 1, 8.

10 C Miller, 'Democratization, International Knowledge Institutions, and Global Governance' (2007) 20 Governance 325, 331. See also, Barnett and Finnemore, 'The 
frame and structure the common and collective understanding of states which might litigate before them, as well as the understanding of the Court itself in terms of how it responds to issues at some future date. ${ }^{11}$

Section 2 of the article includes a description of the conception of power as a diffuse persuasive force, which forms the basis of the discussion which follows. This is followed in section 3 with a brief description of the use of environmental principles in the judgments of the ICJ. The variable nature of the function and role of environmental principles and their potential for social learning are examined in three ways in the sections that follow. Section 4 discusses how environmental principles interplay with the institutional power of the ICJ to frame the negotiations of states post-adjudication. Although it is arguable that this is a functionalist argument as mentioned above, this section asserts that the background knowledge created during the dispute-resolution process makes environmental principles more meaningful for the parties and shapes how they might use them. Section 5 examines the productive power of ideas which are expressed through the ICJ in dealing with legal issues before it, or in generating a common understanding of an open-textured environmental principle. Sections 5(a) and 5(b) examine whether environmental principles as abbreviated abstractions refer to ideas that shape the Court's approach to the legal issues before it. They compare whether the precautionary principle and sustainable development had a diffuse role in producing the Court's approach in the Case Concerning the Gabčikovo-Nagymaros Project (Hungary/Slovakia). ${ }^{12}$ This comparative study aims to assess whether environmental principles can produce how the ICJ develops a common understanding of an interpretive position in relation to issues before it. Section 6 analyses whether the open-textured nature of Principle 2 of the United Nations Declaration on Environment and Development ${ }^{13}$ or Principle 21 of the 1972 Declaration of the United Nations Conference on the Human Environment ${ }^{14}$ has enabled the ICJ to generate a unique common understanding amongst several of its judgments, which is a significant departure from its established understanding in international law.

Power of Liberal International Organizations', above $\mathrm{n} 2$.

11 There are different ways to assess the role and function of international courts and tribunals. For some interesting examples, see R Keohane, A Moravcsik, and A M Slaughter, 'Legalized Dispute Resolution: Interstate and Transnational' (2000) 54(3) International Organization 457; Wessel, above n 5; W Werner, 'Securitization and Judicial Review: A Semiotic Perspective on the Relation Between the Security Council and International Judicial Bodies' (2001) 14 International Journal for the Semiotics of Law 345.

12 Case Concerning the Gabčikovo-Nagymaros Project (Hungary/Slovakia) [1997] ICJ Rep 7 ('Danube Dam Case').

13 UN Doc A/CONF.151/5/Rev.1 (1992) ('Rio Declaration').

14 UN Doc A/CONF.48/14/Rev.1 (1972) ('Stockholm Declaration'). For differences between Principle 21 and 22 and the ICJ's formulation, see E B Weiss, 'Opening the Door to the Environment and to Future Generations' in Laurence B De Chazournes and Philippe Sands (eds) International Law, the International Court of Justice and Nuclear Weapons (1999) 338. 


\section{Power and Social Learning}

There is no doubt that power is a ubiquitous feature of social and political life internationally. Our answers to how it is constituted, enable us to better understand why actors at the international level behave the way they do towards each other and how they collectively form interests in particular matters. The concept of power is more widely interpreted and critiqued than probably any other idea used in the social sciences. ${ }^{15}$ In international relations, the realist conception of power still has a strong pull, although recent scholarship in the area has clearly sought to displace it. ${ }^{16}$ However, there are different ways to conceptually categorise power which can in turn shape how we understand particular events and decisions. Conceptions of power have the potential to shape how we understand and approach the work of formal or informal dispute-resolution institutions at the international level, and how environmental principles frame or structure change through them in international law and politics. This article adopts the conception of power discussed and theorised in international relations by Barnett and Duvall. ${ }^{17}$ The international law literature makes use of the concept of power, but draws upon international relations for its source of sociological inspiration. ${ }^{18}$

Barnett and Duvall define power as the 'production, in and through social relations, of effects that shape the capacities of actors to determine their own circumstances and fate'. ${ }^{19}$ This is quite different from the conception of power that sees it in relational terms. Baldwin, for instance, views power as the 'capacity to get somebody else to do what he or she would not have done otherwise'. ${ }^{20}$ Barnett

15 On varying arguments relating to conceptions of power see generally, S Guzzini, 'Structural Power: The Limits of Neorealist Power Analysis' (1993) 47(3) International Organization 443; S Guzzini, 'The Use and Misuse of Power Analysis in International Theory' in R Palan (ed), Global Political Economy: Contemporary Theories (2000) 53; D Baldwin, 'Power and International Relations' in W Carlsnaes, T Risse and B A Simmons (eds), The Handbook of International Relations (2002) 179.

16 See, for instance, Guzzini, 'Structural Power: The Limits of Neorealist Power Analysis', above n 15; Guzzini, 'The Use and Misuse of Power Analysis in International Theory', above n 15; Baldwin, 'Power and International Relations', above n 15; J Nye, Soft Power: The Means to Success in World Politics (2004).

17 M Barnett and R Duvall, 'Power in Global Governance' in M Barnett and R Duvall (eds), Power in Global Governance (2005) 1; M Barnett and R Duvall, 'Power in International Politics' (2005) 59 International Organization 39. This work draws on Barnett and Duvall because of the particular way they have integrated moderate constructivist orientations into their conceptualisations of power. Also, the various authors whose work appears as part of the edited volume by Barnett and Duvall have adopted parts or all of their descriptions of the various ways to categorise power. For a review of the book by Barnett and Duvall, see S Solomon, 'Power and the Politics of Global Governance' (2006) 8 International Studies Review 327.

18 The relationship between different conceptions of power in international relations and how they relate to international law are considered in R Steinberg and J Zasloff, 'Power and International Law' (2006) 100(1) The American Journal of International Law 64; and in the context of customary international law see Byers, Custom, Power and the Power of Rules, above $\mathrm{n} 5$, esp ch 1.

19 Barnett and Duvall, 'Power in Global Governance', above n 17, 8.

20 D Baldwin, Paradoxes of Power (1989) 7, quoted in Guzzini, 'The Use and Misuse of 
and Duvall would argue that their definition brings together two core dimensions which would differentiate it from Baldwin's. They characterise them as 'the kinds of social relations through which power works, and the specificity of the social relations through which power's effects are produced'. ${ }^{21}$ They use their definition of power and the two dimensions of it to develop a taxonomy which avoids having to prioritise discussions of agency and structure. ${ }^{22}$

Barnett and Duvall's taxonomy of power is represented below in Figure 1. They refer in Figure 1 to the institutional and productive powers which this section describes as expressions of diffused power. In either instance, the real production of the effects of power depends on actors interacting with each other within a social context to collectively learn rather than directly being required to adjust predetermined preferences. Additionally, as discussed in section 2 below, historically the ICJ has not often used its direct power to adjudicate the rights of parties in terms of their obligations to comply with environmental principles. The rest of this section discusses the ideas of institutional and productive power which are applied later in this article.

Figure 1:23 Types of power

\begin{tabular}{llcc} 
& & \multicolumn{2}{c}{ Relational specificity } \\
\cline { 3 - 4 } & & Direct & Diffuse \\
\hline Power works & Interactions of specific actors & Compulsory & Institutional \\
through & Social relations of constitution & Structural & Productive \\
\hline
\end{tabular}

\section{(a) Institutional power}

Barnett and Duvall develop the concept of institutional power to refer to situations where actors indirectly control others through formal or informal institutions which mediate between international actors. ${ }^{24}$ International institutions are examples of situations where states do not exercise direct control over each other but seek to influence the direction of change through their rules and procedures. ${ }^{25}$ What is important for this conception of power is that the institution is not completely dominated by one actor. In fact, Barnett and Duvall draw from scholarship on the

Power Analysis in International Theory', above n 15, 60. On David Baldwin's conceptions of power in international relations see 'Neoliberalism, Neorealism, and World Politics', in D Baldwin (ed), Neorealism and Neoliberalism: The Contemporary Debate (1993) 3; D Baldwin, 'Force, Fungibility, and Influence' (1999) 8(4) Security Studies 173.

21 Barnett and Duvall, 'Power in Global Governance', above n 17, 12.

22 Ibid 12-13.

23 Ibid 12

24 Ibid 15

25 Ibid. 
moderate versions of the social constructivist tradition in international relations, like Abbot and Snidal, ${ }^{26}$ as well as more recently from the work of Barnett and Finnemore, ${ }^{27}$ to argue that it is more likely for institutions to exist independently of 'specific resource-laden actors' ${ }^{28}$ This position is consistent with constructivist ontology, which argues that power and interests do not exist independently of interactions within groups. ${ }^{29}$

The social distance between taking an action and the production of its effects on an actor is a feature of this particular conception of power. As a result of this 'lag between stimulus and effect', the exact effects or results of power cannot easily be identified. ${ }^{30}$ This particular conception sees the potential of power to have effects even when the social relations between actors are at a 'physical, temporal and social distance' from each other. ${ }^{31}$ This means that in institutions, for instance, an actor cannot directly control or exercise power over someone else. Although ultimately the power of an actor might express itself in producing certain effects on others, this will happen in a diffuse way. This is in contrast to the classical realist account of power which see actor A as using their material, normative and symbolic resources to directly control actor B in a particular situation. ${ }^{32}$

Institutional power works through the 'socially extended, institutionally diffuse relations' that parties have with each other. This means that power will only express itself because actors socialise with each other through and within the structures established within the formal or informal institution. Barnett and Duvall's conception of institutional power is different from their conception of power as productive in terms of constituting particular social relations amongst actors. What institutional power shares with productive power is its focus on the diffuse way in which it can have effects on actors.

\section{(b) Productive power}

In contrast to the concept of institutional power, productive power is more concerned with constitutive social processes which are not necessarily controlled by 'specific actors' but which are effected through the 'meaningful practices of actors'. ${ }^{33}$ The social processes that create meaning for actors in terms of what they can do in a particular context also shape their understanding of who they are and what they want. The idea of productive power, according to Barnett and Duvall, is a diffuse and general social process. This means that it is more about systems of

K Abbott and D Snidal, 'Why States Act Through Formal International Organizations' (1998) 42(1) Journal of Conflict Resolution 3.

27 M Barnett and M Finnemore, Rules for the World: International Organizations in Global Politics (2004).

28 Barnett and Duvall, 'Power in Global Governance', above n 17, 16.

29 See, for instance, Steinberg and Zasloff, above n 18, 82.

30 Barnett and Duvall, 'Power in Global Governance', above n 17, 11.

31 Ibid 12

32 Ibid 13-15

33 Ibid 20-21. 
considering the various ways in which actors interplay with reifications and meaning or episteme. ${ }^{34}$

In the context of environmental issues, for instance, anthropocentricism is a system that signifies particular ways in which an actor will relate to others in terms of how they view their relationship to the environment. It is also a discourse, or a 'social process and the systems of knowledge through which meaning is produced, fixed, lived, experienced, and transformed'. ${ }^{35}$ In the context of anthropocentricism, it means that actors will socialise in a way that will shape intersubjectives structure to favour human interests over the environment. As a result, the preferences of actors to protect nature for its own sake will be working against the deeper discourse that underpins the discussions being had about the environment. Drawing from Foucault, Adler and Bernstein have also argued in the context of international relations that knowledge is productive in the sense of defining and constituting the social reality or the order of global things. ${ }^{36}$ Adler and Bernstein use the term 'knowledge' to refer to the power that discourse has to produce particular social facts.

The idea of productive power is built on the conception of power as a 'social process' whereby actors come to see themselves as having particular social identities or capacities in particular situations. ${ }^{37}$ The interaction of individual judges with each other and the litigants throughout the proceedings helps produce the way they interplay with and are constituted by social facts, knowledge or reifications of various kinds, which include norms like environmental principles. This implies that this conception of power is inherently connected with the social learning process which shapes how the ICJ as a group of judges interpret particular facts or the law with which they are dealing. In this sense, power is expressed through the ICJ as opposed to something that it can wield against others.

\section{The International Court of Justice and Environmental Principles}

Various international judicial, tribunal or arbitral bodies have jurisdiction and have dealt with aspects of international environmental law, and in particular have employed environmental principles in their work. ${ }^{38}$ However, there is no single international court, tribunal or arbitral body that is designed to deal solely with

E Adler and S Bernstein, 'Knowledge in Power: The Epistemic Construction of Global Governance' in M Barnett and R Duvall (eds), Power in Global Governance (2005) 294, 294-95. See also V Walsh, Global Institutions and Social Knowledge: Generating Knowledge at the Scripps Institution and the Inter-American Tropical Tuna Commission, 1900s-1990s (2004).

37 Barnett and Duvall, 'Power in Global Governance', above n 17, 9.

38 For a list of these international courts and tribunals and their various contributions to the development of international environmental law, see Stephens, International Courts and Environmental Protection, above n 6. 
international environmental law issues. ${ }^{39}$ The focus of this article is on the ICJ not due to the strength of its contribution to shaping international environmental law but because of its position as the most prominent dispute-settlement body internationally, and because it has a more general jurisdiction than courts and tribunals of issue-specific regimes like the International Tribunal for the Law of the Sea or the World Trade Organization's Dispute Settlement Panel. ${ }^{40}$ In 1993, the ICJ set up a permanent Chamber on Environmental Matters, ${ }^{41}$ but it has yet to deal with a case that raises issues solely dealing with the protection of the environment or natural resources. ${ }^{42}$

It has been argued that dispute settlement has contributed very little to the development of international environmental law. ${ }^{43}$ Although dispute-resolution bodies have not used terms such as 'rules', 'principles' or 'standards' in a consistent way, ${ }^{44}$ the scholarship often questions the functional value of the abstract or open-textured nature of principles in directly resolving particular legal

39 For discussions relating to the need for an international court to deal with environmental matters, see Amedeo Postiglione, The Global Environmental Crisis: The Need for an International Court of the Environment (1996); A Rest, 'The Indispensability of an International Environmental Court' (1998) 7 Review of European Community and International Environmental Law 63.

40 See arts 34 and 36 of the Statute of the International Court of Justice establishing its general jurisdiction over international disputes.

41 International Court of Justice, Communiqué 93/20 on the Establishment of a Permanent Chamber for Environmental Matters (19 July 1993).

42 The Chamber will not play a role in relation to environmental disputes until a particular party to a dispute refers a case to it: S Schwebel, 'Ad Hoc Chambers of the International Court of Justice' (1987) 81 American Journal of International Law 831. On an unsuccessful attempt to refer cases to the Chamber, see the Case Concerning the Gabčikovo-Nagymaros Project (Hungary/Slovakia) [1997] ICJ Rep 7.

43 Stephens, The Role of International Courts and Tribunals in International Environmental Law, above n 6, 9. For studies that have explored the way in which dispute-resolution bodies have used international environmental law, see J M Gillroy, 'Adjudication Norms, Dispute Settlement Regimes and International Tribunals: The Status of "Environmental Sustainability" in International Jurisprudence' (2006) 42 Stanford Journal of International Law 1; J Dunoff, 'Institutional Misfits: The GATT, the ICJ and Trade-Environment Disputes' (1994) 15 Michigan Journal of International Law 1043; T Stephens, 'Multiple International Courts and the "Fragmentation" of International Environmental Law' (2006) 25 Australian Yearbook of International Law 227; Stephens, International Courts and Environmental Protection, above $\mathrm{n} 6$.

44 In 2005, for instance, the arbitral tribunal of the Permanent Court of Arbitration in its decision in the Case Concerning the Iron Rhine ('Ijzeren Rijn') Railway (Belgium v Netherlands) stated that:

[t] here is considerable debate as to what, within the field of environmental law, constitutes 'rules' or 'principles'; what is 'soft law'; and which environmental treaty law or principles have contributed to the development of customary international law ... The mere invocation of such matters does not, of course provide the answer': (2005) Permanent Court of Arbitration [58]-[60] $<$ http://www.pca-cpa.org/upload/files/BE-NL\%20Award\%20240505.pdf $>$ at 15 May 2009>. 
or social problems before them. ${ }^{45}$ This means that the role and function of environmental principles in the adjudication of disputes are classed and described as indeterminate or political in nature. ${ }^{46}$ Perhaps the ethical and aesthetic, rather than purely economic judgments that dominate environmental considerations make problems more protracted. That is, in environmental disputes it is not just the preferences of actors that are central to a conflict but deeper judgments about engagement with what is good or aesthetically valuable in terms of its conservation for the future generation. ${ }^{47}$ The underlying issues in disputes cannot always easily be resolved before the courts by the application of narrow and predetermined rules. Alternatively, abstract and open-textured norms challenge the potential legitimacy of the dispute-resolution body were it to decide in favour of particular ethical or moral positions without appearing to base its judgment on the apparent consensual nature of international law and politics. ${ }^{48}$

The ICJ, in the Advisory Opinion of the Legality of the Threat or Use of Nuclear Weapons, ${ }^{49}$ referred to its own version of what is known as Principle 21 of the Stockholm Declaration or Principle 2 of the Rio Declaration. This was not the first case where the ICJ had dealt with environmental issues, ${ }^{50}$ but it was the

45 For instance, Cesare Romano argues, referring to international environmental disputes, that: 'Adjudication will be resorted to only if the law is fairly, but not too, clear or if the parties agree to give the dispute settlement body a large leeway or even to engage in creative law-making.': C Romano, 'International Dispute Settlement' in D Bodansky, J Brunnée and E Hey (eds), The Oxford Handbook of International Environmental Law (2007) 1036, 1041. It is more common for scholars within international law to refer to the indeterminacy of norms and extrapolate from that the potential that might exist for its ideological abuse. In relation to jus cogens norms, see A L Paulus, 'Jus Cogens in a Time of Hegemony and Fragmentation - An Attempt at a Re-appraisal' (2005) 74(3-4) Nordic Journal of International Law 297. On the ineffectiveness of international courts and tribunals to make good use of broad environmental norms, see T Stephens, 'The Limits of International Adjudication in International Environmental Law: Another Perspective on the Southern Bluefin Tuna Case' (2004) 19(2) The International Journal of Marine and Coastal Law 177.

46 M Koskenniemi, 'Peaceful Settlement of Environmental Disputes' (1991) 60 Nordic Journal of International Law 73.

47 For an example of discussions relating to 'judgment' in environmental ethics, see M Sagoff, Price, Principle, and the Environment (2004) ch 1. For a good discussion of environmental ethics and international environmental law, see C Stone, 'Ethics and International Environmental Law' in D Bodansky, J Brunnée and E Hey (eds), The Oxford Handbook of International Environmental Law (2007) 291.

48 This does not seem to be uniquely an environmental law and politics issue. In the context of human rights, for instance, Marcus has argued that there is a perception that socio-economic rights as abstract and open-textured norms are not justiciable: D Marcus, 'The Normative Development of Socioeconomic Rights Through Supranational Adjudication' (2006) 42 Stanford Journal of International Law 53.

49 Legality of the Threat or Use of Nuclear Weapons (Advisory Opinion) [1996] ICJ Rep 226 ('Nuclear Weapons Case').

50 By 1996, the ICJ had decided the following cases that involved environmental issues: Icelandic Fisheries Case (Federal Republic of Germany v Iceland) [1974] ICJ Rep 3; [1974] ICJ Rep 1975; Nuclear Tests Cases (New Zealand v France) (Interim Measures) [1973] ICJ Rep 135, (Merits) [1974] ICJ Rep 457; Case Concerning 
best opportunity it had to directly apply environmental principles to a dispute before it. ${ }^{51}$ Since its decision in the Nuclear Weapons Advisory Opinion, the ICJ has dealt with many other cases that in some way concern the environment. ${ }^{52}$ In the Danube Dam Case, the ICJ in its judgment referred to more than just its version of Principle 21 of the Stockholm Declaration. This is not to suggest that environmental principles have not been brought up by litigants to other cases before the ICJ or discussed as part of the dissenting opinions of the judges of the ICJ. ${ }^{53}$ However, since the Danube Dam Case, we are yet to see the ICJ, in the

Delimitation of the Maritime Boundary in the Gulf of Maine Area (Canada/United States of America) [1984] ICJ Rep 246; Nauru Case [1992] ICJ Rep 240; Case Concerning Maritime Delimitation in the Area Between Greenland and Jan Mayen (Denmark v Norway) [1993] ICJ Rep 38; Request for an Examination of the Situation in Accordance with Paragraph 63 of the Court's Judgment of 20 December 1974 in the Nuclear Tests (New Zealand v France) Case [1995] ICJ Rep 288.

51 Cases before the ICJ that have concerned themselves somewhat indirectly with environmental harm include the following that deal with the delimitation of maritime jurisdiction: Case Concerning Maritime Delimitation in the Area Between Greenland and Jan Mayen (Denmark v Norway) [1993] ICJ Rep 38; Case Concerning the Land and Maritime Boundary Between Cameroon and Nigeria (Cameroon v Nigeria: Equatorial Guinea Intervening) [2002] ICJ Rep 303; Case Concerning Delimitation of the Maritime Boundary in the Gulf of Maine Area (Canada/United States of America) [1984] ICJ Rep 246. On the relevance of these cases for environmental issues, and sustainability in particular, see Gillroy, above n 43, esp 20-22; Weiss, 'Opening the Door to the Environment and to Future Generations', above n 13. Also see the following two cases before the Permanent Court of International Justice which concerned international watercourses: Case Relating to the Territorial Jurisdiction of the International Commission of the River Oder (Czechoslovakia, Denmark, France, Germany, Great Britain, Sweden/Poland) [1929] PCIJ (ser A) No 23; Diversion of Water from the River Meuse (Netherlands v Belgium) [1937] PCIJ (ser A/B) No 70. Potentially, the ICJ has had opportunities to deal with environmental harm but, for one reason or another, cases before it did not go that far. For instance, in Case Concerning Certain Phosphate Lands in Nauru (Nauru v Australia) [1992] ICJ Rep 240, the ICJ refused jurisdiction to Nauru but the facts of the case would have necessitated a consideration of environmental issues and law.

52 See, for instance, Case Concerning the Gabcikovo-Nagymaros Project (Hungary v Slovakia) [1997] ICJ Rep 7; Fisheries Jurisdiction Case (Spain v Canada) [1998] ICJ Rep 432; Case Concerning Pulp Mills in the River Uruguay (Argentina v Uruguay), (Request for the Indication of Provisional Measures) (2006) 45 ILM 1025, and more recently Ecuador instituted proceedings against Columbia for the aerial spraying of toxic herbicides that is allegedly causing damage to people, animals, crops and the natural environment across its border; see International Court of Justice, 'Ecuador Institutes Proceedings Against Colombia with Regard to a Dispute Concerning the Alleged Aerial Spraying by Colombia of Toxic Herbicides Over Ecuadorian Territory' (Press Release, 1 April 2008).

53 Judge Weeramanty has delivered dissenting opinions in a number of cases discussing the neglect of environmental issues and principles by the Court. For instance, in the Request for an Examination of the Situation in Accordance with Paragraph 63 of the Court's Judgment of 20 December 1974 in the Nuclear Tests (New Zealand v France) Case [1995] ICJ Rep 288, he commented that the:

International Court of Justice, situated at the apex of international tribunals, necessarily enjoys a position of special trust and responsibility in relation to the 
formal and written deliberations that make up its judgment, use established and commonly referred to environmental principles.

The fact that this is the case points to the difficulty of directly applying environmental principles in the context of legal dispute settlement. Importantly, although the ICJ might not commonly use environmental principles to exercise its compulsory power over litigants, this does not indicate whether such principles have a role or function as part of the social learning within the Court. The sections that follow aim to examine the variety of different roles and functions that environmental principles have, and that they could play in relation to the work of the ICJ.

\section{Post-Adjudication Dialogue and Negotiation}

Quite often, scholarship in international law views the judgments of international dispute-resolution bodies as an end to the relevant social context that gives shape to the evolution of a particular dispute and its resolution. ${ }^{54}$ In many instances, negotiations continue beyond the actual litigation before the international dispute resolution body. Given the social nature of interactions during the litigation process, post-conflict dialogue can continue in the shadow of the judicial decisions handed down by the institution dealing with an international dispute. ${ }^{55}$ The institutional structure that sustains this post-conflict dialogue is the traditional diplomatic relationships that states have with each other. It is a collective effort because the ICJ's judgment is integral to the way the parties engage with each other after the relevant judgment has been handed down by the Court. It is in this sense that the ICJ is, notwithstanding the 'social distance', exercising power indirectly and diffusely. ${ }^{56}$ The Court, as discussed in this section, frames social learning and the development of common knowledge amongst the actors by drawing on the open-textured nature of principles to communicate with them during their post-conflict negotiations.

principles of environmental law especially those relating to what is described in environmental law as the Global Commons. (Weeramantry V-P, dissenting at 345).

54 An exception in the area of international environmental law is C P Romano, The Peaceful Settlement of International Environmental Disputes (2000). In relation to the World Trade Organization, see G Shaffer, 'Power, Governance, and the WTO: A Comparative Institutional Approach' in M Barnett and R Duvall (eds), Power in Global Governance (2005) 130.

55 See, for instance, the following two cases that continue for significant periods of time in the shadow of the decision of the ICJ: Case Concerning the Gabcikovo-Nagymaros Project (Hungary/Slovakia) [1997] ICJ Rep 7, 1-72; Nuclear Tests Cases (New Zealand v France) (Merits) [1974] ICJ Rep 457, 253-455. On this issue, see Romano, The Peaceful Settlement of International Environmental Disputes, above n 54, where he discusses both these cases in the context of the impact that the decision of the ICJ had on the dispute.

56 Barnett and Duvall, 'Power in Global Governance', above n 17, 11. 
Barnett and Duvall's conception of institutional power, as discussed earlier in this article, ${ }^{57}$ requires that the institution be independent of the actors who operate within them. Decisions of the ICJ establish that independence by virtue of the judgment they render for and against the parties. That is, the post-conflict negotiations are conducted in the shadow of a judgment that has established certain normative implications for those discussions and created the necessary independence of the actors from each other. A resort to post-conflict negotiations conducted in the shadow of a judgment can give parties further reason to negotiate the real differences between them in terms of the ethical and aesthetic values that are at issue. Barnett and Finnemore have, for instance, argued that international organisations can frame issues in particular ways so that 'desired choices seem particularly compelling'. 58 That is, international organisations can 'structure situations and social understandings in ways that channel behaviour toward some outcomes rather than others'. ${ }^{59}$ International organisations can engage in practices whereby they classify or invent social categories which can then constitute the way actors deal with the social world around them. ${ }^{60}$ Adler and Bernstein, using a similar idea, argue that 'episteme' or intersubjectivity can be mobilised by institutions as a resource to shape what actors take to be valid knowledge or understanding of their social reality. ${ }^{61}$

Environmental principles can be mobilised by the ICJ to frame and structure post-conflict dialogue. The power that the ICJ has is further promoted by giving context to negotiations after the actual litigation has finished. What the litigating parties take as useful or valid for post-conflict negotiations is an expression of this power, which would not be mobilised as easily without environmental principles. The importance of this point is that the litigating parties might not ordinarily use environmental principles to frame and structure their negotiations arising from a particular dispute. However, their interactions with each other, as mediated through the ICJ, give shape to their preferences in a way which might make the use of principles seem natural or the best way to continue to deal with the problems between them. It is in this sense that environmental principles can frame and structure ongoing discussions without giving the impression that participants are compelled to follow particular rules or narrow formulations of what is right or wrong to do. That is, the exercise of power using environmental principles is indirect because its effects are not going to be caused by the Court but rather will depend on how the parties interpret their positions in the light of the environmental principles that gives meaning to how they view their circumstances.

57 See above section II.

58 Barnett and Finnemore, 'The Power of Liberal International Organizations', above n 2, 176-77.

59 Ibid 177. In their own work on international organisations, Barnett and Finnemore at 177-78 highlight how international organisations determine outcomes in the way they set agendas of meetings or classify practices of states.

60 Ibid 178. Barnett and Finnemore draw from the following text in making these points: D Handelman, 'Commentary on Heyman' (1995) 36 Current Anthropology 280.

61 Adler and Bernstein, above n 36, 294-98. 
In doing this, the courts and tribunals interplay with environmental principles to harness their own institutional power in a 'responsive' or 'reflexive' way. The idea that international adjudication might facilitate litigants to resolve their disputes, as opposed to ruling on all aspects of their case, is not new. ${ }^{62}$ Environmental principles give courts and tribunals a chance to facilitate dialogue in a way that is potentially responsive to the needs of each party. In this way, they are central to the exercise of power by courts and tribunals by virtue of their abstraction and the communicative potential that comes with those qualities. However, the power that the Court exercises is dependent on the knowledge that disputing states have about their situation from the decision of the case they are involved with. More importantly, the Court can be seen as creating opportunities for the parties to progressively realise for themselves the implications of environmental principles in the context of their disputes. ${ }^{63}$ In this sense, the environmental principles frame a state's ongoing self-realisation of its interests in the light of the dispute in which it is engaged. This is obviously a different kind of an argument to the power the ICJ might have in terms of principles functioning as a justiciable standard of review of the conduct of parties.

The idea that the ICJ engages with or relies on post-adjudicative negotiations to alleviate the reasons for the dispute arising in the first place finds expression in a number of its decisions. For instance, in the 1984 case on the Delimitation of the Maritime Boundary in the Gulf of Maine Area (Canada/United States of America), ${ }^{64}$ the ICJ had been asked by the United States to consider the ecological conditions of the marine ecosystem in the process of delimiting the Gulf of Maine as between it and Canada. ${ }^{65}$ The proposal was aimed at ensuring that one of the parties to the dispute would have the entire region to maintain the integrity of the ecosystem for straddling stocks of fish. The particular stock was at that time being overfished, and it was becoming endangered as a species. The ICJ decided the case by drawing the boundaries between the two countries across the natural ecosystem and instead indicated that the United States and Canada should cooperate to take care of the environmental challenges caused by the Court's decision. ${ }^{66}$ Gillroy argues that the ICJ refused the sustainability argument put to it and instead opted 'for the more established sovereignty principle of "equity" to create the boundary,

In the context of the Southern Bluefin Tuna Cases, (New Zealand v Japan; Australia $v$ Japan) (Provisional Measures) (1999) 117 ILR 148 and Southern Bluefin Tuna Case (Australia \& New Zealand v Japan) (Jurisdiction and Admissibility) (2000) 119 ILR 508, see D Johnston, 'Fishery Diplomacy and Science and the Judicial Function' (1999) 10 Yearbook of International Environmental Law 33; B Mansfield, 'Letter to the Editor: The Southern Bluefin Tuna Arbitration: Comments on Professor Barbara Kwiatkowska's Article' (2001) 16(2) International Journal of Marine and Coastal Law 361.

63 Marcus, above $\mathrm{n} 48$.

64 Case Concerning Delimitation of the Maritime Boundary in the Gulf of Maine Area (Canada/United States of America) [1984] ICJ Rep 246 ('Gulf of Maine Case').

65 Ibid 278-88. On this case, see also Weiss, 'Opening the Door to the Environment and to Future Generations', above n 13; Gillroy, above n 43, 21-22. 
thus bifurcating the aqua-ecosystem between the two states. ${ }^{67}$ Although in this case the ICJ did not draw on an environmental principle to frame its post-conflict negotiations, it explicitly relied on the fact that the United States and Canada would engage with each other after the litigation to ensure that the ecosystem would not get harmed as a result of the decision by the Court. ${ }^{68}$

In the Fisheries Jurisdiction Case (Germany v Iceland), ${ }^{69}$ the ICJ had to consider whether Iceland could have legally extended its fisheries zone to 50 nautical miles and excluded fishing vessels from it. It decided that Iceland could not have extended its fisheries zone beyond its territorial sea but that it had preferential rights over fisheries resources beyond it. ${ }^{70}$ The ICJ also emphasised conservation measures in several statements, one of which is particularly important for this discussion. This is because of the way the Court connects to future interactions between the parties. It stated that:

both Parties have the obligation to keep under review the fishery resources in the disputed waters and to examine together, in the light of scientific and other available information, the measures required for the conservation and development, and equitable exploitation, of those resources, taking into account any international agreement in force between them. ${ }^{71}$

In this paragraph, the ICJ conceptually maps or frames what the parties need for their interactions with each other beyond the dispute in that case. It situates the decision to grant rights to Iceland within the language of having to negotiate in relation to conservation of the resources.

\section{(a) The Danube Dam Case, post-adjudication and environmental principles}

The argument noted above will now be further illustrated through the work of the ICJ in the Danube Dam Case. This is because it is the most recent example of this kind of interaction between the ICJ and litigants after the formal dispute-settlement process has finished and also because the Court uses the language of environmental norms and principles to guide it. Also, Hungary and Slovakia, in the 1993 Special Agreement Between the Republic of Hungary and the Slovak Republic giving the ICJ jurisdiction to hear the case, had agreed that the Court could also prescribe what the parties should do post-adjudication. ${ }^{72}$ They had already agreed that they

67 Gillroy, above n 43, 21.

68 Weiss quotes the Court as telling the parties that the 'tradition of friendly and fruitful cooperation' between them would be used productively to prevent harm and ensure the conservation of the species. Weiss, 'Opening the Door to the Environment and to Future Generations', above n 13, 341 (referring to the Gulf of Maine Case [1984] ICJ Rep 246, [344]).

69 Fisheries Jurisdiction Case (Germany v Iceland) (Merits) [1974] ICJ Rep 175.

70 Ibid at [44]-[45].

71 Ibid at [64]. See also ibid at [37] in relation to comments by the Court as to the importance of conservation of fish stocks.

72 See art 2(1) of the Special Agreement Between the Republic of Hungary and the Slovak Republic for Submission to the International Court of Justice of the Differences between them concerning the Gabčíkovo-Nagymaros Project, opened for 
would further negotiate with each other once the Court had issued its ruling. ${ }^{73}$ As a result, the ICJ judgment not only declared what the rights of the parties were in that case, but also prescribed what they should do in their post-adjudication negotiations.

In the Danube Dam Case, Hungary had argued that, because of 'new requirements of international law for the protection of the environment', it was 'precluded' from performing the 1977 Treaty Concerning the Construction and Operation of the Gabč́kovo-Nagymaros System of Locks 74 with Czechoslovakia. ${ }^{75}$ The 1997 Treaty had envisaged, amongst other things, that two locks would be constructed, one at Gabčíkovo (now Slovakia) and the other in Nagymaros (in Hungary). A dam would also be built at Dunakiliti, which is in the Hungarian portion of the Danube. These projects would develop the energy and navigational needs of both countries as well as protect particular parts of the countries from flooding. When Hungary pulled out of the project, one of its arguments related to the belief that further participation in the project would not be consistent with Hungary's obligations to protect the environment, water quality and fisheries of the Danube. Hungary had argued that the project would be inconsistent with its international obligation to prevent environmental harm and the Slovak Republics' obligations to avoid serious environmental harm. ${ }^{76}$

Around 1991, Hungary showed little interest in working further on the project. Czechoslovakia (as it was in 1991) started constructing an overflow dam in Cunovo and later diverted the Danube through it. The effect of this diversion on riparian areas of the Danube in Hungary was considerable. This was in addition to reducing the total quantity of water that flowed through the Hungarian portion of the Danube. Before the ICJ, Hungary had argued that the diversion of the Danube and the damage it had done were, amongst other matters, a breach of international

signature 7 April 1993, (1993) 32 ILM 1293 (entered into force 28 June 1993).

73 See ibid art 5.

74 Opened for signature 16 September 1977, (1993) 32 ILM 1247 (entered into force 30 June 1978) ('1977 Treaty').

75 Case Concerning the Gabčikovo-Nagymaros Project (Hungary/Slovakia) [1997] ICJ Rep 7, [111]. This description is not meant to be comprehensive, given that the arguments made in these sections do not need certain details from the case. For an excellent description of the facts and the processes leading to the judgment by the ICJ, see Aaron Schwabach, International Environmental Disputes: A Reference Handbook (2005), esp 51-59. For discussions of the legal issues, see A A-Khavari and D Rothwell, 'The ICJ and the Danube Dam Case: A Missed Opportunity for International Environmental Law?' (1998) 22 Melbourne University Law Review 507; C Schulte, Compliance with Decisions of the International Court of Justice (2004) ch 24; Romano, The Peaceful Settlement of International Environmental Disputes, above n 54, 246-60; P Sands, 'International Courts and the Application of the Concept of "Sustainable Development"' (1999) Max Planck Yearbook of United Nations Law 389.

76 Memorial of the Republic of Hungary in the Case Concerning the GabcikovoNagymaros Project (Hungary $v$ Slovakia) vol 1 (2 May 1994) 198-203 $<$ http://www.icj-cij.org/docket/index.php?p1 $=3 \& \mathrm{p} 2=3 \& \mathrm{k}=8 \mathrm{~d} \&$ case $=92 \&$ code $=$ hs\&p3=1>, at 15 May 2009. 
environmental laws. ${ }^{77}$ The specific points raised related, amongst other matters, to the obligation not to cause damage to the environment beyond ones border, and the need to give prior notification to neighbouring states of activities that might cause significant damage to their environment. ${ }^{78}$ The ICJ rejected both these arguments relating to the termination of the 1977 Treaty by pointing out that articles 15,19 and 20 allowed for these new and emerging concerns relating to the environment to be integrated into the bilateral contractual relationship. ${ }^{79}$ The Court in turn argued that emerging environmental norms actually enhanced the relevance of articles 15 , 19 and 20 of that treaty for the parties as they negotiated their Joint Contractual Plan to implement the agreement. ${ }^{80}$ The Court said that 'newly developed norms of environmental law' were 'relevant' to the ongoing discussions because they could use articles of the 1977 Treaty to agree on ways to integrate them into their negotiations.

The Court remained vague and ambiguous about what these 'newly developed norms of environmental law' were. ${ }^{81}$ In the Danube Dam Case, a reference to the pleadings of Hungary, which had more strenuously developed its environmental arguments, makes it clear that it drew heavily from environmental principles in developing its arguments. In particular, the precautionary principle as an expression of the more general principle of preventing harm to the environment gave shape to Hungary's arguments about terminating its obligations in relation to the 1977 Treaty. ${ }^{82}$ In relation to the diversion of the Danube to operate the Gabčíkovo power plant, Hungary had argued, amongst other things, that this was in breach of Czechoslovakia's (now Slovakia) obligation not to cause damage to the environment beyond its sovereign borders. ${ }^{83}$ These arguments clearly reflect those arising out of Principle 21 of the Stockholm Declaration and Principle 2 of the Rio Declaration. Additionally, Hungary also argued that Slovakia had an obligation to give it prior notification and to consult with it in relation to the construction of

77 For Hungary's pleadings before the Court in relation to its allegations that Czechoslovakia had illegally diverted the Danube, see ibid 219-33.

78 Ibid 198-203.

79 Case Concerning the Gabčikovo-Nagymaros Project (Hungary/Slovakia) [1997] ICJ Rep 7, [112].

80 Ibid.

81 In the Nuclear Tests Case (New Zealand v France) (Merits) (1995) ICJ Rep 288, at para 64 the ICJ had stated that its order was "without prejudice to the obligations of states to respect and protect the natural environment, obligations to which both New Zealand and France have in the present instance reaffirmed their commitment'. However, the Court made no reference to what obligations it might be referring to. In discussing the Nuclear Tests Cases (New Zealand v France) (merits), P Sands, 'Pleadings and the Pursuit of International Law: Nuclear Tests II (New Zealand $v$ France)' in A Anghie and G Sturgess (eds), Legal Visions of the 21st Century: Essays in Honour of Judge Christopher Weeramantry (1998) 601, 604-06, has argued that reference to the pleadings will give 'juridical assistance' to understanding what the Court might have had in mind.

82 Memorial of the Republic of Hungary in the Case Concerning the GabcíkovoNagymaros Project (Hungary v Slovakia) vol 1, above n 76, 198-203.

83 Ibid 219-23. 
Variant $\mathrm{C}$ and diversion of the Danube. This argument was based on, for example, Principle 19 of the Rio Declaration. ${ }^{84}$

What is most striking when one compares the arguments of Hungary with the final prescriptive judgment of the ICJ is the similarities in the kind of environmental principles it ended up referring to in its judgment compared with those Hungary used in its pleadings before the Court itself. First, it should be noted that the ability of the Court to make such a recommendation was only possible because articles 15, 19 and 20 were very generally worded to allow Hungary and Slovakia, in the process of drafting their future Joint Contractual Plans, to negotiate with each other in relation to the quality of the water of the Danube (art 15), the protection of nature (art 19) and fisheries (art 20). For instance, article 15 provided that the: 'Contracting Parties shall ensure, by the means specified in the joint contractual plan, that the quality of the water in the Danube is not impaired as a result of the construction and operation of the System of Locks. ${ }^{85}$

This meant that, in the context of doing what the 1977 Treaty between them provided, Hungary and Slovakia had to think about how new norms could progressively be applied to their particular situation. In this sense, the Court's prescriptions were contextualised within the relationship that Hungary and Slovakia had already developed. Therefore, Hungary's reference to environmental principles must naturally form the basis of any argument as to what those 'new norms' must be, and in particular the way it must have shaped the manner in which the Court phrased its prescriptive formulations for Hungary and Slovakia in their post-adjudicative negotiations. The Court's judgment in this respect provided that it:

is mindful that, in the field of environmental protection, vigilance and prevention are required on account of the often irreversible character of damage to the environment and of the limitations inherent in the very mechanism of reparation of this type of damage. ${ }^{86}$

This reference to the precautionary principle was further supported and built on when the Court also referred to sustainable development as a way forward for the parties to 'reconcile economic development with protection of the environment' ${ }^{87}$ One might argue that the exercise of institutional power to establish the precautionary principle and sustainable development (for instance) as a communicative norm in this particular context was paying lip service to the issue. However, from the Court's perspective, it had found fault in the conduct of both parties in ways that encouraged them to further negotiate. It had also found that

Ibid 223-28. Principle 19 provides that:

[s]tates shall provide prior and timely notification and relevant information to potentially affected States on activities that may have a significant transboundary environmental adverse effect and shall consult with those States 85 Ibid 184.

86 Case Concerning the Gabčíkovo-Nagymaros Project (Hungary/Slovakia) [1997] ICJ Rep 7, [140].

Ibid. 
Slovakia had breached the 1979 Treaty and the law on watercourses by diverting the Danube into a variant $\mathrm{C}$ of the dam system that it had constructed to avoid economic loss. The application of the more determinate and closed rules to the case allowed the Court to engage both parties in a way that would have no impact on, or would maintain its own legitimacy as, a dispute-resolution body.

Since the ICJ's judgment, Slovakia and Hungary have not yet reached an agreement on implementation of the ruling. ${ }^{88}$ The two countries were meant to have concluded an agreement in 2006 but this has not happened as yet. The effort made to move forward cooperatively reveals that the work of the ICJ was decisive in giving direction to the environmental concerns raised during the case. In 2001, a draft agreement between Hungary and Slovakia describing how they would proceed in their negotiations identified sustainable development and the principle of precaution as two guiding norms. ${ }^{89}$ Additionally, minutes of 2006 meetings held between the two states reveal that they adopted a number of international agreements as between them to give further guidance in terms of their negotiations. ${ }^{90}$ This is important given that Slovakia, during the litigation before the ICJ, had emphasised the social and economic impacts of the diversion of the Danube rather than environmental concerns. ${ }^{91}$

What is instructive about this discussion is that the power of the Court over the litigants in the post-adjudication phase was framed by emphasising that their 1977 Treaty could not properly be implemented in the future without reference to environmental norms. This was so even though the Court did not use environmental principles to declare whether or not the parties had acted properly in relation to the situation before them. This exercise of diffuse power over post-

See United Nations Department for Economic and Social Affairs, Division for Sustainable Development, International Rivers and Lakes Newsletter No 43 (2005) 3 $<\mathrm{http}$ //www.un.org/esa/sustdev/sdissues/water/rivers lakes newsletter.htm> at 15 May 2009; Beata Balogová, 'Slovakia Again Discussing Completion of Gabčíkovo-Nagymaros' Slovak Spectator (4 January 2006) $<$ http://www.spectator.sk/articles /view/21981> at 15 March 2009.

89 Preamble to the Draft Agreement Concluded between the Republic of Hungary and the Slovak Republic for the Purpose of Giving Effect to the Judgment of the International Court of Justice of 25 September $1997<$ http://www.gabcikovo. gov.sk/doc/ prop/agreement-draft-02-04-01a.htm> at 15 May 2009.

90 Minutes of the Meeting of the Working Group on Legal Matters of the Delegations of the Government of the Slovak Republic and the Government of the Republic of Hungary on the Implementation of the Judgement of the International Court of Justice in the Case Concerning the Gabčíkovo - Nagymaros Project held in Budapest on 27 February $2006<$ http://www.gabcikovo.gov.sk/doc/prop/060227_zapEN.htm> at 15 May 2009. Two examples include the adoption of the Convention on Cooperation for the Protection and Sustainable Use of the Danube, opened for signature 29 June 1994, (1996) 19 International Environment Reports 997 (entered into force 22 October 1998); and the Convention on Wetlands of International Importance, Especially as Waterfowl Habitat, opened for signature 2 February 1971, 996 UNTS 245 (entered into force 21 December 1975) ('Ramsar Convention'). These two agreements adopt important standards for the protection of the environment of freshwater and rivers.

91 See in particular section 5(b) for further discussion on the issue. 
adjudicative negotiations was only possible because the Court defined the interests of parties in particular ways during the litigation. Additionally, were it not for the environmental principles, the Court might not have placed such emphasis on the dynamic nature of articles 15, 19 and 20 of the 1977 Treaty. The meaning of such broad provisions within the 1977 Treaty was potentially established intersubjectively by the ICJ's directive that they needed to be understood in the context of other environmental norms.

The open-textured nature of the norms allowed for the exercise of institutional power by the ICJ in ways that more determine and defined rules would not have been able to achieve. This is because of the impact this kind of decision would have on the Court's legitimacy and presence as an international institution created to do what it was precisely seen as delegating. However, the open-textured nature of the environmental principles contains a sufficient degree of intersubjectivity for the Court to use the contours of the norms for the court to defer making policy decisions for the parties, and instead create opportunities for them to give direction to how they will commonly identify with each other. In a way, the ICJ might indirectly be acknowledging the fact that the social or real interests of the parties might be resolved by opening up the legal domain in a way that allows for this to happen. ${ }^{92}$

\section{Productive Power and Environmental Principles in the Danube Dam Case}

Gillroy has examined whether the principle of sustainable development is used by courts and tribunals as an adjudicatory norm ${ }^{93}$ — that is, not as a norm capable of being used directly by parties to generate propositions about their position in relation to the other litigants, but by the Court to resolve international disputes. This is partly consistent with the argument that Lowe made in a powerfully argued piece discussing the normative potential of sustainable development in ordering principles and rules in international dispute resolution. ${ }^{94} \mathrm{~A}$ different line of scholarship also argues that environmental principles such as sustainable development facilitate intra-disciplinary integration amongst norms. ${ }^{95}$ This argument, put forward initially by Boyle, views the role of environmental principles as reformulating 'existing bodies of law' by integrating sustainable development into the development of other bodies of law such as for instance,

92 W Witteveen, 'Turning to Communication in the Study of Legislation' in N Zeegers, W Witteveen and B van Klink (eds), Social and Symbolic Effects of Legislation Under the Rule of Law (2005) 17, 20.

93 Gillroy, above n 43.

94 Vaughan Lowe, 'Sustainable Development and Unsustainable Arguments' in A Boyle and D Freestone (eds), International Law and Sustainable Development: Past Achievements and Future Challenges (1999) 19.

95 International Law Association, Toronto Conference - International Law on Sustainable Development (2006) $17<\mathrm{http}: / /$ www.ila-hq.org/pdf/International \%20Law \%20on\%20Sustainable\%20Development/ Report\%202006.pdf> at 15 May 2009. 
fisheries law or water law. ${ }^{96}$ An alternative way to phrase this approach is to argue that the concept or idea of sustainable development can 'penetrate older terminology', especially when it is being applied some time in the future. ${ }^{97}$ These various discussions appear to draw from the potential productive power of the idea of sustainable development in shaping the way courts, tribunals and litigants before them constitute the world to which they are seeking to give meaning and the reconciliation of different pulls on their preferences. ${ }^{98}$ Contrary to Lowe, Gillroy's sustained and detailed examination of the decisions of the various international courts and tribunals shows that sustainable development is not an adjudicatory norm, even though he argues that it has a status as a principle of international law. ${ }^{99}$

Sustainable development, however, is inherently linked to the idea of protecting the future generation, though it does not specify whether anything in particular must be sustained for them. Sustainability, in other words, is not a particularly high standard to meet in terms of the minimum that is required to protect the interest of the future generation. As an abbreviated and abstract environmental principle, it points to varying conceptions of how society and its relationship to nature can be socially constituted by different actors and groups. For instance, in a dispute about protecting an entire ecosystem, some might argue that it is necessary to maintain its

96 Ibid (emphasis in original). See also International Law Association, Report of the Seventy-First Conference - Berlin (2004) 608-09.

97 A Boyle, 'Relationship Between International Environmental Law and Other Branches of International Law' in D Bodansky, J Brunnée and E Hey (eds), The Oxford Handbook of International Environmental Law (2007) 125, 131.

98 Adler and Bernstein have used the word 'epistemes' to describe the discourses that have produced how actors use to view the world: Adler and Bernstein, above n 36, 295. The idea of 'episteme' in the context of the work of the ICJ has been raised in section 4. Episteme is 'the background intersubjective knowledge - collective understandings and discourses - that adopt the form of human dispositions and practices that human beings use to make sense of the world': Adler and Bernstein, above $\mathrm{n} 36,295$. This background knowledge, they argue, produces institutions in particular ways. The application of this idea to international courts and tribunals is not new. For instance, Sandholtz and Sweet, in discussing the World Trade Organisation (WTO) dispute-settlement regime, have argued that, amongst other norms, the most favoured nation principles generated a 'sophisticated, relatively autonomous domains of legal discourse, replete with their own stable or argumentation frameworks': W Sandholtz and A S Sweet, 'Law, Politics, and International Governance' in C ReusSmit (ed), The Politics of International Law (2004) 238, 254 (footnotes omitted). They point out at 254 that, by the 1980 s, an understanding of the most favoured nation principle 'could only be understood in light of the argument frameworks curated by the panels' of the General Agreement on Tariffs and Trade (GATT) (emphasis in original). That is, the WTO dispute settlement regime produced the way that certain ideas about trade could be internationally understood.

99 Gillroy, above $\mathrm{n} 43,2$. He examines the concept in the work of the ICJ, the World Trade Organization's Appellate Body, the International Tribunal for the Law of the Sea, and also the Human Rights Committee of the United Nations. He argues at 50 that the notion of sovereignty produces the responses of the ICJ against sustainability; and the WTO's Appellate Body defines itself by promoting economic efficiency, which trumps sustainability as an adjudicatory norm. 
current condition because it would otherwise deprive the future generation of clean air. Others might equally argue that sustainability requires that the area also be preserved because it has aesthetic benefits as well. ${ }^{100} \mathrm{~A}$ useful way of exploring whether a tribunal or court itself, as an institution, is constructed by the discourse or episteme to which sustainable development or other environmental principles point is to examine its reaction to issues before it in the context of whether it changes established ideas or socially learns how to respond differently to qualitative tests in legal propositions before it. It is through the actual social practises of a court like the ICJ that we can understand the meaning and function of environmental principles, and potentially their ability to produce what the Court does in context.

In the following discussion in sections $5(\mathrm{a})$ and $5(\mathrm{~b})$, the roles of the precautionary principle and sustainable development respectively are analysed in the context of the Danube Dam Case. The question examined in each section is whether the respective environmental principles produced how the Court approached the legal issues before it.

\section{(a) Ecological necessity and the precautionary principle}

In the Danube Dam Case, the ICJ was asked by Hungary to consider whether its abandonment of the 1977 Treaty between itself and Czechoslovakia (at that time) was necessary because of the imminent peril to the ecological condition of the Danube, which constituted an essential interest of Hungary. ${ }^{101}$ This argument was based on article 33 of the International Law Commission's (ILC) Draft Articles on State Responsibility, ${ }^{102}$ which the ICJ recognised as reflecting customary law. ${ }^{103}$ Article 33(1)(a) gives a state the ability to avoid its international law obligations if what it did 'was the only means of safeguarding' an 'essential interest' it had 'against a grave and imminent peril'. ${ }^{104}$

100 See Sagoff, above n 47, esp ch 2 for a discussion of sustainability and varying conceptions of it in the light of philosophical and ethical approaches to the protecting the environment.

101 Case Concerning the Gabčikovo-Nagymaros Project (Hungary/Slovakia) [1997] ICJ Rep 7, [49]-[58]. See also Memorial of the Republic of Hungary in the Case Concerning the Gabčikovo-Nagymaros Project (Hungary v Slovakia) vol 1, above $\mathrm{n} 76,283-98$. On this issue and how it relates to the precautionary principle, see Daniel Dobos, 'The Necessity of Precaution: The Future of Ecological Necessity and the Precautionary Principle' (2001) 17 Fordham Environmental Law Journal 375.

102 International Law Commission, Draft Articles on State Responsibility (1980) 2(2) Yearbook of the International Law Commission 20 ('Draft Articles on State Responsibility'). On the concept of ecological necessity in the work of the ILC, see J Crawford, The International Law Commission's Articles on State Responsibility (2002) esp 180-82.

103 Case Concerning the Gabčíkovo-Nagymaros Project (Hungary/Slovakia) [1997] ICJ Rep 7, [51].

104 International Law Commission, Draft Articles on State Responsibility, August 4, 1998, 37 ILM 44. See also the Report of the International Law Commission on the Work of Its Thirty-Second Session, UN Doc A/CN.4/318/ADD 49 (1980). 
For the purpose of this discussion, the key portion of Hungary's argument which caused difficulties was whether the damage caused by the diversion of the Danube by Slovakia was perilous and imminent. ${ }^{105}$ The Court, however, examined whether the abandonment of the 1977 Treaty, as a whole, by Hungary could have been justified on the basis that the imminent peril of the entire project (and not just the Variant C that Slovakia had constructed in breach of the 1977 Treaty) necessitated stopping work on the project. The Court therefore sought to interpret whether the potential harm inherent in the entire project established by the 1977 Treaty was imminent and perilous.

The Court's interpretation of the terms 'imminent' and 'peril' in article 33(1)(a) of the Draft Articles on State Responsibility, and its application to the facts of the case, highlight how the precautionary principle in this situation failed to frame its approach. The Court said the following in relation to these words:

The word 'peril' certainly evokes the idea of 'risk'; that is precisely what distinguishes 'peril' from material damage. But a state of necessity could not exist without a 'peril' duly established at the relevant point in time; the mere apprehension of a possible 'peril' could not suffice in that respect. It could moreover hardly be otherwise, when the 'peril' constituting the state of necessity has at the same time to be 'grave' and 'imminent'. 'Imminence' is synonymous with 'immediacy' or 'proximity' and goes far beyond the concept of 'possibility'. 106

This view of article 33(1)(a) presumes that a peril must be unavoidable at the time it is said to eventuate if a state is allowed to evoke the state of necessity argument. ${ }^{107}$ The Court went on to find that the perils claimed by Hungary were 'uncertain' in 1989 when Hungary took steps to terminate its obligations under the 1977 Treaty. ${ }^{108}$ It appears to have been looking for scientific 'certainty' in terms of whether there was likely to be some kind of peril for the essential interests of the state of Hungary. The Court was certainly not bothered by the argument that the potential peril, if ascertained with certainty, might be in the future because it stated that:

a 'peril' appearing in the long term might be held to be 'imminent' as soon as it is established, at the relevant point in time, that the realization of that peril, however far off it might be, is not thereby any less certain and inevitable. ${ }^{109}$

The key reason for rejecting Hungary's argument therefore appears to have been its assessment of the 'uncertainty' of whether the project was sufficiently perilous to warrant terminating it.

Memorial of the Republic of Hungary in the Case Concerning the GabcikovoNagymaros Project (Hungary v Slovakia) vol 1, above n 76, 289-90.

106 Case Concerning the Gabcíkovo-Nagymaros Project (Hungary/Slovakia) [1997] ICJ Rep 7, [54].

107 See E Preiss, 'The International Obligation to Conduct an Environmental Impact Assessment: The ICJ Case Concerning the Gabčíkovo-Nagymaros Project' (1999) 7 New York University Environmental Law Journal 307.

108 Case Concerning the Gabčikovo-Nagymaros Project (Hungary/Slovakia) [1997] ICJ Rep 7, [57].

109 Ibid [54] 
As stated above, the Court did acknowledge that the term 'peril' evoked the idea that the material damage had not actually occurred, but that there was a 'risk' it might happen. The ILC in its commentary on the Draft Articles on State Responsibility does not appear to have said anything about the level of scientific certainty required to assess the nature of a 'peril'. ${ }^{110}$ Therefore, the Court in this case had the potential to determine for itself whether it would make a policy choice to adopt the idea that the reference to the level of risk in the term 'peril' had to be established with certainty or could be left uncertain. ${ }^{111}$ It has been argued that the precautionary principle refers to 'uncertain risk' rather than requiring states to take preventative action when risk has been established with certainty. ${ }^{112}$ Hungary, in its written memorial to the ICJ in the Danube Dam Case, referred to the precautionary principle as an expression of the concept of prevention in international environmental law. In this way, it also highlighted the ideas of the uncertainty of risk. ${ }^{113}$

The difference between certain and uncertain risk is in the 'link of cause and effect between an event that might occur and the damage anticipated as a result'. 114 What is risky about the certainty of the event occurring or the unpredictability of it is '[o]nly the length of time that will elapse'. ${ }^{115}$ In the context of the Danube Dam Case, the ICJ argued that 'dangers ascribed to the upstream reservoir were mostly of a long-term nature and, above all, that they remained uncertain'. ${ }^{116}$ That is, the Court was more concerned in this case with establishing the certainty of harm than worrying about the risk of whether it would occur or not at some time in the future.

Clearly, the Court was not dismissing the need to prevent environmental harm. At one point, it said that:

110 On this, see also Dobos, above n 101.

111 On this important distinction between certain and uncertain risk, see M van Asselt and E Vos, 'The Precautionary Principle and the Uncertainty Paradox' (2006) 9(4) Journal of Risk Research 313. On the difference it makes in the context of legal disputes, see N de Sadeleer, Environmental Principles: From Political Slogans to Legal Rules (2005); N de Sadeleer, 'The Effect of Uncertainty on the Threshold Levels to which the Precautionary Principle Appears to be Subject' in M Sheridan and L Lavrysen (eds), Environmental Law Principles in Practice (2002) 32. See also H Nowotny, P Scott and M Gibbons, Re-Thinking Science: Knowledge and the Public in an Age of Uncertainty (2001).

112 van Asselt and Vos, above n 111, 314; de Sadeleer, Environmental Principles, above n 111, 156-61.

113 Memorial of the Republic of Hungary in the Case Concerning the GabcikovoNagymaros Project (Hungary $v$ Slovakia) vol 1, above n 76, 201-03.

114 de Sadeleer, Environmental Principles, above n 111, 158.

115 Ibid 159. See also de Sadeleer, 'The Effect of Uncertainty on the Threshold Levels to which the Precautionary Principle Appears to be Subject', above n 111, 32-36.

116 Case Concerning the Gabčikovo-Nagymaros Project (Hungary/Slovakia) [1997] ICJ Rep 7, [55]. 
In the field of environmental protection, vigilance and prevention are required on account of the often irreversible character of damage to the environment and of the limitations inherent in the very mechanism of reparation of this type of damage. ${ }^{117}$

Nonetheless, it did adopt an interpretation of 'imminent' and 'peril' which favoured prevention as opposed to precaution. It seems to have ignored the debates and discussions relating to 'uncertainty'. 118 This suggests that the precautionary principle has yet to have a productive effect on framing the power the Court will exercise in determining issues before it.

In appears from this discussion that the Court was being conservative about its own role in the resolution of disputes involving claims of uncertain risk to the environment. Its interpretation of art 33(1)(a) of the Draft Articles on State Responsibility as requiring certain risk in relation to establishing a 'peril' meant that the Court was also restricting any opportunities states might have to abuse the potential of this provision, which it claimed is now part of customary international law. It presumes the capacity of a state to be able to prove with certainty whether harm will occur or not in making out a case for ecological necessity. It is also arguable that the Court has changed the potential nature of the issues that future litigants might raise before it where they might involve claims based on the precautionary principle.

\section{(b) Equitable utilisation and sustainable development}

In 1997, Hungary, in its submission to the ICJ in the Danube Dam Case, argued that Variant $C$ took away between 40 and 43 per cent of the 50 per cent of the waters of the Danube that would otherwise be available for its use. ${ }^{119}$ Slovakia had argued, however, that Variant $\mathrm{C}$ was a 'justified countermeasure to Hungary's illegal acts'. ${ }^{120}$ The ICJ responded to Slovakia's argument by declaring that it had deprived Hungary of its right to equitably use the Danube as a natural resource. The Court also noted that one of the legal effects of its decision was that, in interpreting articles 15, 19 and 20 of the 1977 Treaty, it had to 'look afresh at the effects on the environment of the operation of the Gabčíkovo power plant' using 'new norms' and 'new standards'. ${ }^{121}$ This discussion looks more closely at the Court's declaration relating to the lack of proportionality in Slovakia's countermeasures against Hungary.

117 Ibid [140].

118 For a good summary discussion of uncertainty and risk in relation to the use of precautionary principle in international law, see A Trouwborst, Precautionary Rights and Duties of States (2006).

119 Memorial of the Republic of Hungary in the Case Concerning the GabcikovoNagymaros Project (Hungary v Slovakia) vol 1, above n 76, 229. The Court itself notes that 'Variant $\mathrm{C}$ led Czechoslovakia to appropriate, essentially for its use and benefit, between 80 and 90 per cent of the waters of the Danube before returning them to the main bed of the river' (Case Concerning the Gabčikovo-Nagymaros Project (Hungary/ Slovakia) [1997] ICJ Rep 7, [78].

120 Case Concerning the Gabčikovo-Nagymaros Project (Hungary/Slovakia) [1997] ICJ Rep 7, [85].

121 Ibid [140]. 
Hungary had argued that the diversion had deprived it of its right to 50 per cent of the flow of the Danube. Slovakia had argued, however, that Variant C was in fact the optimal way to use the Danube given that the relevant circumstances were brought about by Hungary's intentions to terminate the Treaty. ${ }^{122}$ Importantly, Slovakia drew on article 6 of the 1991 ILC draft articles on the Law of NonNavigational Uses of International Watercourses 123 to argue that the relevant criteria for determining what was equitable and reasonable included those relating to the social and economic impacts of the diversion rather than the environmental criteria. ${ }^{124}$ This was in total contrast to Hungary's arguments, which relied on environmental considerations relating to the equitable and reasonable use of the Danube as a resource.

The portion of the Court's judgment in the Danube Dam Case which is discussed in this section is extracted here to facilitate a closer reading of it. The Court wrote:

In the view of the Court, an important consideration is that the effects of a countermeasure must be commensurate with the injury suffered, taking account of the rights in question.

In 1929, the Permanent Court of International Justice, with regard to navigation on the River Oder, stated as follows:

122 Memorial of the Slovak Republic in the Case Concerning the Gabcíkovo-Nagymaros Project (Hungary v Slovakia) vol 1 (2 May 1994), [302]-[304] <http://www.icjcij.org/docket/index.php?p1 $=3 \& \mathrm{p} 2=3 \& \mathrm{k}=8 \mathrm{~d} \&$ case $=92 \&$ code $=\mathrm{hs} \& \mathrm{p} 3=1>$ at 15 May 2009.

123 Draft Article on the Law of the Non-Navigational Uses of International Watercourses (1991) 2(2) Yearbook of the International Law Commission 66 ('1991 ILC draft articles on watercourses'). These Draft articles were amended in 1994 and again in 1997 before the UNGA approved them by 103 votes (with three against and 27 abstentions) as the United Nations Convention on the Law of Non-Navigational Uses of International Watercourses, opened for signature 21 May 1997 (1997) 36 ILM 700 (not in force) ('Watercourses Convention'). On the history and analysis of the agreement, see S McCaffrey and R Rosenstock, 'The International Law Commission's Draft Articles on International Watercourses: An Overview and Commentary' (1996) 5(2) Review of European Community and International Environmental Law 89; S McCaffrey, The Law of International Watercourses (2 ${ }^{\text {nd }}$ ed, 2007) 217. On international watercourses more generally, see P Wouters (ed), International Water Law: Selected Writings of Professor Charles B Bourne (1997); E Benvenisti, 'Collective Action in the Utilization of Shared Freshwater: The Challenges of International Water Resources Law' (1996) 90 The American Journal of International Law 384; S McCaffrey and M Sinjela, 'The 1997 United Nations Convention on International Watercourses' (1998) 92 American Journal of International Law 97.

124 Their submission to the Court at Paragraph 7.8 states that: 'Whether on the basis of (b) "the social and economic needs of the watercourse state concerned", (c) "existing and potential uses of the watercourse", or (f) "the availability of alternatives, or corresponding value, to a planned or existing use", Variant "C" is clearly an equitable and reasonable utilisation, and lawful.': Memorial of the Slovak Republic in the Case Concerning the Gabčikovo-Nagymaros Project (Hungary v Slovakia) vol 1, above n 122, 304. 
[the] community of interest in a navigable river becomes the basis of a common legal right, the essential features of which are the perfect equality of all riparian States in the user of the whole course of the river and the exclusion of any preferential privilege of any one riparian State in relation to the others' ...

Modern development of international law has strengthened this principle for non-navigational uses of international watercourses as well, as evidenced by the adoption of the Convention of 21 May 1997 on the Law of the Non-Navigational Uses of International Watercourses by the United Nations General Assembly.

The Court considers that Czechoslovakia, by unilaterally assuming control of a shared resource, and thereby depriving Hungary of its right to an equitable and reasonable share of the natural resources of the Danube - with the continuing effects of the diversion of these waters on the ecology of the riparian area of the Szigetkoz - failed to respect the proportionality which is required by international law. ${ }^{125}$

In this part of its judgment, the Court endorses the idea, initially developed in the Case Relating to the Territorial Jurisdiction of the International Commission of the River Oder, ${ }^{126}$ that there is a 'common legal right' to a 'community of interest in a navigable river'. ${ }^{127}$ It claimed that this right had been strengthened through '[m]odern' developments of it 'in international law'. ${ }^{128}$ Slovakia could not have 'unilaterally' assumed 'control of a shared resource' - namely the Danube - and as a result deprived 'Hungary of its right to an equitable and reasonable share of the natural resources of the Danube'. ${ }^{129}$ Earlier in its judgment, the Court had also confirmed the importance and relevance of the idea of equitable and reasonable use when it declared that Hungary had not 'forfeited its basic right to an equitable and reasonable sharing of the resources of an international watercourse' just because it had violated its terms by not continuing to implement them. ${ }^{130}$ In this sense, the Court simply confirmed the presence of a right to an equitable and reasonable share of a natural resource, and acknowledged the rights states had to not have it unilaterally taken away from them by a state upstream to them.

In highlighting the presence of this right to equitably and reasonably use an international watercourse, the Court referred to the 1997 Watercourses Convention. ${ }^{131}$ However, it did not make explicit reference to article 5, which actually codifies the idea upon which it had drawn. ${ }^{132}$ In relation to the Court's

Case Concerning the Gabčikovo-Nagymaros Project (Hungary/Slovakia) [1997] ICJ Rep 7, [85].

126 [1929] PCIJ (ser A) No 23, [27].

127 Case Concerning the Gabcíkovo-Nagymaros Project (Hungary/Slovakia) [1997] ICJ Rep 7, [85]. On the concept of a 'community of interest' and its modern relevance, see McCaffrey, The Law of International Watercourses, above n 123, 147-67.

128 Case Concerning the Gabčíkovo-Nagymaros Project (Hungary/Slovakia) [1997] ICJ Rep 7, [85].

129 Ibid.

130 Ibid 78

131 Opened for signature 21 May 1997 (1997) 36 ILM 700 (not in force).

132 Case Concerning the Gabćikovo-Nagymaros Project (Hungary/Slovakia) [1997] ICJ Rep 7, [85]. It is interesting to note that Slovakia, in its argument, made extensive 
pronouncement of the disproportionate nature of the countermeasure taken by Slovakia, Higgins has written that the:

Court must be taken to have linked the unilateral control to its finding that Hungary was deprived of an equitable and reasonable share of the natural resource. And it appears to have determined that such a deprivation cannot be proportionate to any prior illegality relating to the watercourse (and not just that the deprivation caused in the instant case was disproportionate to the prior illegalities of suspension and abandonment). ${ }^{133}$

What is interesting about this observation is that there is nothing wrong with a state, on its own, deciding how to use an international river. This is so, as long as its decision does not impact on the potential of other states to enjoy equitable use of the same international watercourse. 134 What is therefore at issue, and which Higgins does not really get to, is what Hungary was in fact deprived of that was so significant to have made the unilateral decision of Slovakia so meaningful for the Court. It is therefore clear that the group of judges deciding the case must have had something else at the back of their minds when making this rather difficult and yet crucial pronouncement in terms of the rights and interests of Slovakia in particular. That is, it could not have been the concern that Slovakia had decided unilaterally to take away Hungary's right to a natural resource. McCaffrey also confirms the vagueness of the ICJ's approach when he voices his interest in the way the Court rejected Slovakia's claim to having taken a proportionate countermeasure. He has written that 'it is remarkable that the Court seemed to believe it was obvious that Slovakia's diversion was per se a disproportionate response to Hungary's internationally wrongful act'. ${ }^{135}$ McCaffrey is suggesting that the Court must have weighed Slovakia's actions in contrast to the disadvantages for Hungary.

This is important because it has been argued that either actual or potential transfrontier harm is not in itself problematic unless a state can show that, because of this, it has lost its right to an equitable and reasonable utilisation of the international watercourse. ${ }^{136}$ The Court certainly voiced its concern over the impact of Variant $\mathrm{C}$ on Hungary. It pointed out that the diversion of the Danube had 'continuing effects' on the ecology of the riparian area of the Szigetkoz. ${ }^{137}$

reference to the 1991 ILC draft Articles on Watercourses, above n 123, instead of the much later ones: Memorial of the Slovak Republic in the Case Concerning the Gabcikovo-Nagymaros Project (Hungary v Slovakia) vol 1, above n 122, 302. The ICJ did in fact refer to article 5(2) of the 1977 Watercourses Convention in a later part of its judgment: Case Concerning the Gabčikovo-Nagymaros Project (Hungary/Slovakia) [1997] ICJ Rep 7, [147].

133 R Higgins, 'Natural Resources in the Case Law of the International Court' in A Boyle and D Freestone (eds), International Law and Sustainable Development: Past Achievements and Future Challenges (1999) 101, 110.

134 See, eg, I Kaya, Equitable Utilization: The Law of the Non-Navigational Uses of International Watercourses (2003) 151-79.

135 McCaffrey, The Law of International Watercourses, above n 123, 217.

136 Kaya, above n 134, 169.

137 Case Concerning the Gabčikovo-Nagymaros Project (Hungary/Slovakia) [1997] ICJ Rep 7, [85]. 
Nevertheless, the Court avoided evoking the idea that 'no harm' must come to any watercourse state and thereby gave priority to the idea of equitable and reasonable utilisation. ${ }^{138}$ This is confirmed by the fact that the ICJ did not refer to article 7 of the 1997 Watercourses Convention, which is also important in the context of this discussion. Article 7 provides that 'watercourse States shall ... take all appropriate measures to prevent the causing of significant harm to other watercourse states'.

It is important to look to article 5(1) of the 1997 Watercourses Convention to understand this puzzling but crucial part of the judgment of the Court, ${ }^{139}$ It provides that:

Watercourse States shall in their respective territories utilize an international watercourse in an equitable and reasonable manner. In particular, an international watercourse shall be used and developed by watercourse States with a view to attaining optimal and sustainable utilization thereof and benefits therefrom, taking into account the interests of the watercourse States concerned, consistent with adequate protection of the watercourse. ${ }^{140}$

What is important about article 5(1) is that, in its draft form — namely the 1991 and 1994 ILC draft articles on watercourses - there was no reference to the term 'sustainable' in the context of what equitable and reasonable utilisation might mean to states. The Preamble to the 1997 Watercourses Convention also identifies sustainable utilisation as an important goal to promote for the 'present and future generations' and which was not present in the 1991 and 1994 version of the same instrument. It must be noted, however, that the 1997 Watercourses Convention had been adopted on 21 May 1997 by the General Assembly of the United Nations (UNGA) (four months before the case was heard by the Court), meaning that its status as customary law was still debatable and the instrument had certainly not come into force as a treaty at the time the ICJ was referring to it. Despite these comments, the Convention did reflect around 20 years of work by the ILC. ${ }^{141}$

What stands out in article 5(1) is the idea that, to equitably and reasonably use an international watercourse, a state must take the sustainable and optimal use of the natural resource into account. Article 5(1) does not say that this has to be an explicit part of the consideration, but a meaningful assessment of equitable use cannot ignore sustainability. Some have argued that the concept of equitable and reasonable use of a watercourse is synonymous with the idea of using it sustainably. ${ }^{142}$ Importantly, considerations of sustainability potentially add new elements to what is equitable and reasonable in the sense that they bring to the forefront the needs of the future generation. That is, one big difference between

138 For a discussion of 'equitable and reasonable utilisation' in the context of the 1997 Watercourses Convention, see C B Bourne, 'The Primacy of the Principle of Equitable Utilization in the 1997 Watercourses Convention' (1997) 35 Canadian Yearbook of International Law 221.

139 The Court's finding that Slovakia had acted disproportionately meant it failed in its main claim for damages against Hungary.

140 Emphasis is mine.

141 McCaffrey, The Law of International Watercourses, above n 123, 216.

142 See, for instance, Kaya, above n 134, 179-83. 
equitable and sustainable utilisation is the presence of the future generation in producing the Court's power over the litigation. In fact, before the 1997 Watercourses Convention was approved by the UNGA, writers had argued that the concept of equitable utilisation and the criteria for determining it did not value the future generation properly. ${ }^{143}$ The reference to the future generation in the Preamble of the 1997 Watercourses Convention also confirms this new priority of the agreement as highlighted in article 5(1).

From this, one might conclude that the unsustainability of Variant $\mathrm{C}$ lies in the impact it would have had on the future generation because of the effects not only of the water quality of the river but the riparian areas of Szigetkoz which the Court itself highlighted in its judgment. ${ }^{144}$ As a result, the unilateral control of the river is significant in terms of its implications for the future generation. This conclusion, though not obvious on an immediate reading of paragraph [85] of the judgment, is confirmed implicitly in paragraph [140] where the Court wrote that 'this need to reconcile economic development with protection of the environment is aptly expressed in the concept of sustainable development'. More importantly it continued to say that:

For the purposes of the present case, this means that the Parties together should look afresh at the effects on the environment of the operation of the Gabčíkovo power plant. In particular they must find a satisfactory solution for the volume of water to be released into the old bed of the Danube and into the side-arms on both sides of the river. 145

This reference to needing to reconsider their operations in the light of concerns about sustainable development adds support to the observations about why the Court might have decided that Slovakia's diversion of the Danube was disproportionate as a countermeasure to what Hungary had done. The inability to properly formulate what the rights of the future generation might be worth could have given enough reason to the Court to avoid a discussion of it in its judgment.

Sustainable development in its interplay with the power of the Court produced an alternative possibility for the application of the equitable utilisation of international watercourses in the Danube Dam Case. It is accurate to suggest that the Court learnt through its interaction with Hungary and Slovakia that the articulation of sustainability in article 5(1) of the 1997 Watercourses Convention was necessary. This is important given the lack of apparent connections before this case between the concepts of equitable utilisation and sustainable development. ${ }^{146}$ Sustainable development appears to have functioned not as a norm with a particular fixed meaning, but as an episteme that gave context and direction to what the Court

143 See M Erdem, 'Sustainable Utilisation of International Watercourses: A Legal Overview’ (1992) 12 Istanbul University International Law Bulletin 41.

144 Case Concerning the Gabčikovo-Nagymaros Project (Hungary/Slovakia) [1997] ICJ Rep 7 [85].

145 Ibid [140].

146 A Boyle, 'The Gabčíkovo-Nagymaros Case: New Law in Old Bottles' (1997) 8 Yearbook of International Environmental Law 13. 
was being asked to do in relation to the equitable use of an international watercourse. The power of the Court was disciplined in favour of giving extra protection to the environment in circumstances that could just as easily have tipped in favour of the social and economic priorities of managing watercourses. In this sense, sustainable development appears to have heightened the awareness of the Court in favour of existing norms that states had adopted which favoured the environmental dimension of the use of international rivers.

In contrast to the above discussion in section 5(a) on the precautionary principle, it is arguable that sustainable development had more of a productive effect on the Court because it interpreted equitable utilisation in favour of environmental concerns raised by Hungary. This is in contrast to its interpretation of 'imminent peril', which did not favour the more environmentally sensitive approach that could have been produced by the Court had the precautionary principle had more of an effect on it. However, the differences between the two situations are important in terms of the way that the Court's power over Hungary and Slovakia was produced. In assessing what 'imminent peril' meant, the Court did not appear to have any other evidence from, for instance, the Draft Articles on State Responsibility, which would have suggested that the practices of states favoured giving credence to 'uncertain' risks to the natural environment. In interpreting what 'equitable utilisation' of a watercourse referred to in assessing what Hungary had been deprived of, the Court instead had the 1997 Watercourses Convention which, although it had not come into force at the time it was delivering its judgment, was reflective of years of drafting work by the ILC. In other words, the approach of the Court to how it assessed whether Slovakia had deprived Hungary of its right to equitable utilisation of the Danube was socially constructed through the productive effect that sustainable development had on the Court's power.

\section{Productive Power of Protecting the Future Generation and Transboundary Harm}

The discussion in this section continues to explore the interplay between principles and productive power, but from a different perspective. It examines whether the open-textured nature of some environmental principles can function as frames which help the ICJ to develop a common understanding of deeper philosophical views on how the environment should be protected. The significance of this discussion lies in highlighting how the ICJ can potentially develop unique positions on environmental issues which can then be used in litigation before it, as well as in the development of international law more generally.

In the Corfu Channel Case (United Kingdom v Albania), the ICJ noted that 'certain general and well-recognized principles' were binding on Albania, one of which was that every state had an 'obligation not to allow knowingly its territory to be used for acts contrary to the rights of other States'. ${ }^{147}$ Although the Corfu

147 [1949] ICJ Rep 4 ('Corfu Channel Case'). This norm will hereinafter be referred to as the 'transboundary harm principle.' 
Channel Case did not involve an environmental dispute, various scholars use the transboundary harm principle identified by the Court to indicate that, as far back as 1949, the ICJ had made statements 'pertinent to transboundary environmental issues'. ${ }^{148}$ The transboundary harm principle, in its different formulations, has been described as the 'cornerstone of international environmental law'. ${ }^{149}$ It was originally raised as a norm in the Trail Smelter Case (Canada/United States of America) arbitration decision involving Canada and the United States. ${ }^{150}$ Although not in the form stated by the ICJ in later cases, it was codified in Principle 21 of the Stockholm Declaration and then in similar terms by Principle 2 of the Rio Declaration. ${ }^{151}$ The version that appears in Principle 21 of the Stockholm Declaration identifies that:

States have, in accordance with the Charter of the United Nations and the principles of international law, the sovereign right to exploit their own resources pursuant to their own environmental policies, and the responsibility to ensure that activities within their jurisdiction or control do not cause damage to the environment of other States or of areas beyond the limits of national jurisdiction. ${ }^{152}$

148 Sands, 'Pleadings and the Pursuit of International Law', above n 81, 629; N Horbach and P Bekker, 'State Responsibility for Injurious Transboundary Activity in Retrospect' (2003) 50 Netherlands International Law Review 327, 343-344. On this point, see also the dissenting opinion of Judge Weeramantry V-P in Request for an Examination of the Situation in Accordance with Paragraph 63 of the Court's Judgment of 20 December 1974 in the Nuclear Tests (New Zealand v France) Case [1995] ICJ Rep 288, where at 362 he notes that the:

Corfu Channel case laid down the environmentally important principle that, if a nation knows that harmful effects may occur to other nations from facts within its knowledge and fails to disclose them, it will be liability to the nation that suffers damage.

149 P Sands, Principles of International Environmental Law (2 ${ }^{\text {nd }}$ ed, 2003) 236; X Hanqin, Transboundary Damage in International Law (2003); G Handl, 'Transboundary Impacts' in D Bodansky, J Brunnée and E Hey (eds), The Oxford Handbook of International Environmental Law (2007) 531. However, others point to the fact that the principle is simply about protecting the territorial integrity of a sovereign: K Bosselmann, 'Environmental Governance: A New Approach to Territorial Sovereignty' in R Goldstein (ed), Environmental Ethics and Law (2004) 293, 301.

150 Trail Smelter Case (Canada/United States of America) (1938 and 1941) 3 RIAA 1911. On this topic, see more generally R Bratspies and R Miller (eds), Transboundary Harm in International Law: Lessons from the Trail Smelter Arbitration (2006).

151 For discussions of the differences between Principle 21 of the Stockholm Declaration and Principle 2 of the Rio Declaration and the IJCs formulation, see also Weiss, 'Opening the Door to the Environment and to Future Generations', above n 13.

152 Principle 2 of the Rio Declaration encourages states to exploit 'their own resources pursuant to their own environmental and developmental policies'. The inclusion of the terms 'developmental policies' in Principle 2 has been criticised - see, for instance, D Wirth, 'The Rio Declaration on Environment and Development: Two Steps Forward and One Back, or Vice Versa' (1995) 29 Georgia Law Review 599, and M Pallemaerts, 'International Environmental Law from Stockholm to Rio: Back to the Future' (1992) 1 Review of European Community and International Environmental Law 254. 
It has been argued that if the Trail Smelter Arbitration were to be retried, it would not be decided any differently, given the way international environmental law has evolved since that case. ${ }^{153}$ Interestingly, in the Trail Smelter Arbitration, Canada did not have to stop operating the smelter that caused the pollution but rather had to ensure that its activities were harmless to the territory of the United States. Horbach and Bekker, argue that, because of the precautionary principle, the onus of proof that is on states in the light of the transboundary harm principle may in fact change. ${ }^{154}$ As a result, some types of domestic activities might now cause 'certain types of significant transboundary harm (biosafety or biodiversity injury)', whether it is today or at some time in the future, and which may need to be stopped. ${ }^{155}$ They also point out that this view is consistent with a reading of article 1 of the 2001 Draft Articles on the Prevention of Transboundary Harm from Hazardous Activities adopted by the ILC. 156 This observation by Horbach and Bekker suggests that the transboundary harm principle appears to have a core which has not been modified. However in its application one has to become increasingly aware of the risk associated with certain types of activities that are not currently unlawful under international law. ${ }^{157}$

The ICJ has confirmed a version of the transboundary harm principle which not only reproduces a core idea common amongst many definitions of the norm but, because of its open-textured nature, has produced it in a new form by drawing on a variety of novel ideas and concepts. Given that this formulation is similar but also different to what appears, for instance, in the 2001 ILC Transboundary Harm Convention, or earlier in Principle 21 of Stockholm Declaration or Principle 2 of the Rio Declaration, it is arguable that the social learning is uniquely that of the ICJ. It is, however, the interaction of the ICJ with the productive power of the idea of needing to protect the future generation that has provided further nuance to the open-textured nature of the transboundary harm principle in this instance. ${ }^{158}$ As a

153 Horbach and Bekker, above n 148, 367-70.

154 Ibid 370.

155 Ibid.

156 Report of the International Law Commission, 53rd Session, UN Doc A/56/10 (2001) ('ILC Transboundary Harm Convention'). Article 1 outlines the scope of the Convention, stating that: 'The present draft articles apply to activities not prohibited by international law which involve a risk of causing significant transboundary harm through their physical consequences.' See also Prue Taylor, An Ecological Approach to International Law: Responding to Challenges of Climate Change (1998), esp ch 4.

157 This is also consistent with the historical reasons as to why the ILC separated its discussion of the rule of state responsibility which it later codified in the Draft Articles on Responsibility of States for Internationally Wrongful Acts, Report of the International Law Commission, 53rd Session, UN Doc A/56/10 (2001) (noted in GA Res 56/83, UN Doc A/RES/56/83 (2001)), and those acts that are not unlawful but which have injurious consequences for states: Draft Articles on the Prevention of Transboundary Harm from Hazardous Activities, Report of the International Law Commission, 53rd Session, UN Doc A/56/10 (2001).

158 This work uses the notion of protecting the future generation as an idea that is collectively held amongst groups of actors. It is its instantiation in norms like the transboundary harm principle which confirms the idea that it is part of the collective 
result, the open-textured nature of the transboundary harm principle has allowed the ICJ to establish how it identifies with the idea of protecting the future generation from environmental harm. The rest of this section will show how the version of the transboundary harm principle which was developed and has now been adopted by the ICJ through a number of cases is unique, and how its construction is a reflection of the interplay between the productive power deployed within the ICJ and the principle.

In 1994, the UNGA asked the ICJ for an Advisory Opinion as to whether according to international law the threat or use of nuclear weapons was permitted under any circumstances ${ }^{159}$ Amongst other matters, the Court had to consider whether the various formulations of the transboundary harm principle that had been put to it would be violated were nuclear weapons to be used by any state. ${ }^{160}$ In delivering its judgment in the Nuclear Weapons Case, the ICJ also developed its own language for giving expression to the transboundary harm principle when it stated that:

the environment is not an abstraction but represents the living space, the quality of life and the very health of human beings, including generations unborn. The existence of the general obligation of States to ensure that activities within their jurisdiction and control respect the environment of other States or of areas beyond national control is now part of the corpus of international law relating to the environment. ${ }^{161}$

The ICJ has since confirmed this exact expression of the principle in statements in important cases such as the Danube Dam Case, ${ }^{162}$ and most recently when it provided Provisional Orders in the Case Concerning Pulp Mills in the River Uruguay (Argentina $v$ Uruguay). ${ }^{163}$ Arguably, it is now in a form that, because of its repetition in several judgments, can be used by others in the future when they litigate before the Court. Although it is possible to suggest that the version of the transboundary harm principle is unique to the facts of the Nuclear Weapons Case, ${ }^{164}$ its repetition using the exact formulation in subsequent judgments suggests that this is now a debatable issue.

identity of actors more generally. See, J DesJardins, Environmental Ethics: An Introduction to Environmental Philosophy ( $4^{\text {th }}$ ed, 2005), esp ch 4, 74-86. See also, Sagoff, above $\mathrm{n} 47$. For an alternative view in international relations see Stone, above n 47.

159 Legality of the Threat or Use of Nuclear Weapons (Advisory Opinion) [1996] ICJ Rep 226, [1].

160 Ibid [27].

161 Ibid [29]. On this case more generally, see John Burroughs, The (Il)legality of Threat or Use of Nuclear Weapons: A Guide to the Historic Opinion of the International Court of Justice (1997).

162 Case Concerning the Gabčikovo-Nagymaros Project (Hungary/Slovakia) [1997] ICJ Rep 7, [140].

163 Case Concerning Pulp Mills in the River Uruguay (Argentina v. Uruguay) (Request for the Indication of Provisional Measures) (2006) 45 ILM 1025, [72] ('River Uruguay Case (Provisional)').

164 See, eg, Stephens, The Role of International Courts and Tribunals in International 
A number of differences can be observed between the two different versions of the transboundary harm principle developed by the ICJ in the Corfu Channel Case and the Nuclear Weapons Advisory Opinion. These differences include:

1 the focus of the principle is now not just on sovereign territorial space but also areas of the world that are beyond national control; 165

2 the idea that states must 'respect' the environment as a unique addition to how it has been previously formulated and which suggests a level of care beyond what one is obligated to; ${ }^{166}$ and

3 an explicit statement that the environment includes the interests that the future generation might have in the 'living space' of humans, and that we must 'ensure that they have some quality to their lives and can remain healthy'.

In relation to the first point, the original formulation of the transboundary harm principle did not include any references to the global commons. ${ }^{167}$ Although Principle 21 of the Stockholm Declaration and Principle 2 of the Rio Declaration refer to areas that are beyond the 'limits of national jurisdiction', the ICJ specifies more precisely that the parts of the world which are beyond territorial boundaries are important for the purposes of the transboundary harm principle. In other words, the extension of the principle for the ICJ is apparent, but it is limited in terms of areas that are potentially a 'living space' for humans or might impact our health in some way. Importantly, this formulation by the ICJ appears to go further than what is specified in the 2001 ILC Transboundary Harm Convention. ${ }^{168}$ In article 2(c), for instance, it limits the scope of its provisions to harm caused by states to places that are 'under the jurisdiction or control of a State'. ${ }^{169}$ This extension of the principle by the ICJ stands out, given that it has been commented that the ILC was 'cautious to develop' the articles in the Convention 'along the lines established by related international instruments, in particular the principles embodied in the Rio Declaration of 1992, the Stockholm Declaration of $1972 \ldots{ }^{\prime} 170$ The implication of the extension of the transboundary harm principle in this way by the ICJ is important because it can potentially apply to situations that involve multiple actors

Environmental Law, above n 43, 143, fn 150, who has suggested that Principle 21 of the Stockholm Declaration could not have been used because nuclear weapons could cause much harm to the natural environment of the world and not just to those of neighbouring states.

See, eg, K Leigh, 'Liability for Damage to the Global Commons' (1992) 14 Australian Year Book of International Law 129.

166 For another examination of the use of the word 'respect' by the ICJ, see Weiss, 'Opening the Door to the Environment and to Future Generations', above n 14.

167 See, for instance, Leigh, above n 165.

168 Draft Articles on the Prevention of Transboundary Harm from Hazardous Activities, Report of the International Law Commission, 53rd Session, UN Doc A/56/10 (2001).

169 Article 2(c) provides that: "“Transboundary harm" means harm caused in the territory of or in other places under the jurisdiction or control of a State other than the State or origin, whether or not the States concerned share a common border.'

170 B Simma, 'The Work of the International Law Commission at Its Fifty-Third Session (2001)’ (2002) 71 Nordic Journal of International Law 123, 138. 
and include harm to the global commons, such as the depletion of the ozone layer. ${ }^{171}$

Second, the ICJ raises the prospect that the word 'respect' in the context of the transboundary harm principle changes the threshold required for assessing what states are allowed to do to areas outside of their jurisdiction. ${ }^{172}$ The commentary on the 2001 ILC Transboundary Harm Convention identifies the terms 'significant', 'serious' and 'substantial' as some of words used in judgments and treaties to describe existing thresholds for assessing whether the damage caused to territory outside of a state's jurisdiction should attract liability. ${ }^{173}$ The 2001 ILC Transboundary Harm Convention actually adopted the term 'significant transboundary harm' as the threshold for what states should avoid. ${ }^{174}$ In its commentaries to the Convention, the ILC noted that the term 'significant' involves 'more factual considerations than legal determination'. ${ }^{175}$ It noted that the term 'significant', while determined by factual and objective criteria, also involves 'a value determination which depends on the circumstances of a particular case and the period in which such determination' is to be made. ${ }^{176}$ Clearly, the term 'respect' is a much more open-textured notion than the phrase 'do not cause', which appears in Principle 21 of the Stockholm Declaration and is far more value driven than the term 'significant', which is used in article 3 of the 2001 ILC Transboundary Harm Convention. ${ }^{177}$ The reason for making this distinction is that the ICJ leaves open the possibility that, in arguing before it, a state might be able to include, for instance, a broader 'category of environmental expenses, including monitoring and assessment expenses and actual clean-up costs'. ${ }^{178}$ Weiss has also

171 See P S Rao, 'Environment as a Common Heritage of Mankind: A Policy Perspective' in International Law on the Eve of the Twenty-First Century: Views from the International Law Commission: réflexions de codificateurs (1997) 201, 213, referred to in Horbach and Bekker, above n 148, fn 49. See also P S Rao, 'International Liability for Transboundary Harm' (2004) 34(6) Environmental Policy and Law 224, 227.

172 The ICJ in the Nuclear Weapons Case [1996] ICJ Rep 226, [30] also used the word 'respect' in the context of the necessity and proportionality of measures aimed at selfdefence. It said: 'Respect for the environment is one of the elements that go to assessing whether an action is in conformity with the principles of necessity and proportionality.'

173 International Law Commission, 'Commentary on the Draft Articles on Prevention of Transboundary Harm from Hazardous Activities' (2001) 2(2) Yearbook of the International Law Commission 144, 152.

174 Article 3 of the Draft Articles on the Prevention of Transboundary Harm from Hazardous Activities, Report of the International Law Commission, 53rd Session, UN Doc A/56/10 (2001) requires that: 'The State of origin shall take all appropriate measures to prevent significant transboundary harm or at any event to minimize the risk thereof.'

175 International Law Commission, above n 173, 152.

176 Ibid 153.

177 The Trail Smelter Case (Canada/United States of America) (1938 and 1941) 3 RIAA 1911 used the words 'serious consequence'.

178 Horbach and Bekker, above n 148, 367, use these words to describe the significance of the work of Panel 'F4' of the Panels of Commissioners for the United Nations 
argued that the use of the word 'respect', rather than 'do not cause', imposes a broader obligation on states than that required by Principle 21 of the Stockholm Declaration and Principle 2 of the Rio Declaration. ${ }^{179}$

Lastly, from a philosophical or ethical perspective the ICJ appears to be stating that our relationship with the environment should unashamedly continue to be anthropocentric. ${ }^{180}$ The basis for acting to prevent transboundary harm is simply because of the particular value that nature has for human beings. This view of the principle has an impact on the direct or indirect responsibility states have to protect the natural world within another jurisdiction or globally if it has apparent value for human beings. Although this sounds critical, this approach of the ICJ to the transboundary harm principle is important for highlighting the way that its power has been produced by its concern over the future generations. That is, the rights of future generations are in themselves an abstraction which needs to be specified. In valuing nature in term of a 'living space' as well as for the 'quality of life and the very health of human beings', the ICJ appears to be specifying the areas where emphasis must be placed in terms of the transboundary harm principle. Importantly, the ICJ also suggests that states are no longer just concerned with the impact that transboundary harm has on the sovereignty of other states, but with people and their relationship to the natural environment.

The above discussion shows that the ICJ commonly identifies with a particular approach to the transboundary harm principle in international law and politics which it has reaffirmed over several judgments, including the Nuclear Weapons Case, the Danube Dam Case and also the River Uruguay Case (Interim). There are significant differences between its approach to the principle and, for instance, the codification of it in the 2001 ILC Transboundary Harm Convention. The environmental principle in this case gave creative support to what the ICJ did in developing a common understanding within the Court of what transboundary harm means. In this process, the ICJ might have shown leadership internationally in defining more broadly some of the elements upon which states might rely in generating ideas about their rights and responsibilities. This is important because of the limited reach of the 2001 ILC Transboundary Harm Convention.

Functionally, the ICJ's particular conception of the transboundary harm principle might have opened up the potential it has to encourage communication amongst actors before damage occurs because of its reliance on the idea that states have to 'respect' the environment of others. That is, the value judgment involved in terms of what 'respect' means is significantly more subjective than the alternatives

Compensation Commission ( $<$ www.unog.ch/uncc $>$ ) in relation to the environmental issues before them. On the United Nations Compensation Commission more generally, see R Lillich (ed), The United Nations Compensation Commission (1995).

179 See Weiss, 'Opening the Door to the Environment and to Future Generations', above n 13,340 .

180 Anthropocentricism values the environment in terms of what it offers to human beings. On the ethical approaches to international environmental law, see A Gillespie, International Environmental Law, Policy and Ethics (2000). 
like 'significant', 'serious' or 'substantial'. A state is likely, under this conception of the principle, to have to engage in impact assessment of projects and conduct other due diligence activities in consultation with neighbouring states. This is especially needed if there is the potential that their activities within their jurisdiction might not show 'respect' towards those of the neighbouring state. In this sense, the ICJ was able to use the open-textured nature of the environmental principle to redefine it in a way that still maintained its core connection with other formulations of it in, for instance, the 2001 ILC Transboundary Harm Convention. It was also able to provide a nuanced view of it that is more in line with protecting the interests of the people who live in neighbouring states, whose environment might otherwise get harmed from a lack of due diligence by other states.

\section{Conclusion}

The ICJ has not frequently used environmental principles in determining the legal positions of parties appearing before it. ${ }^{181}$ As this article has shown, this does not necessarily mean that such principles have not contributed to the way the ICJ has positioned itself in changing international law and politics. In terms of the three different ways in which the role and function of environmental principles were examined, it appears that the ICJ has been most directly engaged with the transboundary harm principle, and has generated a common understanding of it that is significant in the context of international law more generally. Its open-textured nature has meant that ideas about protecting the future generation have been able to produce the Court's approach to it and distinguish its meaning from other efforts to regulate behaviour in relation to environmental harm that is not unlawful under international law. Although states have yet to use it directly in litigation before the Court, it also has potential for creating expectations in international law and politics more generally. Also, given the potential discussed earlier in this work for other international courts and tribunals to draw from the jurisprudence of the ICJ, the collective social learning within the Court in this respect is significant for change in law and politics through dispute resolution,

The analysis in this respect has also highlighted how open-textured environmental principles which have a long history of development in international law might create opportunities for the Court to shape and advance its own common understanding of environmental issues. Clearly, the fact that the ICJ has been willing to adopt a more environmentally focused view of the transboundary harm principle than the 2001 ILC Transboundary Harm Convention is important. It suggests that there is potential amongst the Bench to construct meaning from its own interactions with disputing parties rather than confining itself to norms in conventions and treaties..

However, the approach of the Court to whether environmental principles, as an abbreviated abstraction, can constitute or produce the way it approaches its interpretation of legal provisions and issues is not so promising. A closer examination of the pleadings of both Hungary and Slovakia in the Danube Dam

181 See discussion in section 3 of this work. 
Case showed that parties have commonly relied on environmental principles in making their arguments to the Court. The interactions amongst the parties in that case, however, failed to convince the Court that its views of 'imminent peril' should develop alongside a precautionary approach to how nature is valued. In contrast, in its approach to the concept of 'equitable utilisation', the Court appears to have been influenced by the ideas captured by sustainability in its abbreviated form. This does not necessarily suggest that sustainable development played a significant role, given that article 5(1) of the 1997 Watercourses Convention could also have shaped how the Court interpreted the concept of 'equitable utilisation'. However, neither Hungary nor Slovakia relied on the 1997 Watercourses Convention and neither argued in terms of sustainability. ${ }^{182}$ It is therefore possible, that concerns over sustainability had a diffuse effect on how the Court asserted itself, in relation to Slovakia's diversion of the Danube as a countermeasure against Hungary.

The engagement of Hungary and Slovakia with the Court in the Danube Dam Case has created an expectation that it might once again emphasise environmental harm as an aspect of what constitutes proportionality in the context of countermeasures. However, compared with the interplay between the precautionary principle, sustainable development and productive power through the ICJ, it does not seem certain that environmental principles are likely to play a significant role in collective social learning within the Bench in this respect. That is, the interpretations by the Bench of established norms in the Danube Dam Case were not significantly swayed by either of these two principles. However, given the Court's approach to sustainability, it is arguable that environmental principles might constitute the way the Court interprets legal issues - especially if other treaties or conventions can confirm their approach. If international environmental law continues to develop in the light of concerns over the harm we cause to the natural environment, its principles might increasingly constitute how the Court exercises its interpretive powers over established norms. In this sense, environmental principles could develop greater significance for learning within the Court and collective understanding emerging from it.

Lastly, it was argued that the social interaction of states post-adjudication is made meaningful by the Court's diffuse exercise of power, which may be ideologically framed, amongst other factors, by environmental principles. The process of litigating is itself a social activity whereby the preferences of states are shaped during it. Environmental principles contextualised within this social process have the potential to encourage diplomatic relationships to progressively reveal what the actors' interests might be in the context of the overall dispute beyond the litigation itself. In these contexts, environmental principles as abstract or opentextured norms are important because they function as norms with the potential to communicate with parties beyond the case. In this sense, environmental principles

182 Hungary's arguments were set against the damage that the diversion would cause to its environment and natural resource. 
can identify for the parties a greater range of ideas and possibilities to use in their negotiations, in contrast to rules that are closed normatively.

The work of the ICJ in dispute resolution is not an easy case through which to study the role and function of environmental principles. Despite this, the power of the Court appears to be constituted in different ways by the potential that environmental principles have to help it create meaning from its interactions with disputing litigants. Importantly, it appears that the variable nature of the ways in which groups of actors socially learn to intersubjectively associate with each other or develop a common knowledge about something are important for understanding the role and function of environmental principles in bringing about change at the international level. In the context of the study discussed in this article, the abstract and open-textured nature of environmental principles has meant that their function and role are subtler than expected in their effects on the learning process. 